\title{
Středobronzový metalický depot Moravský Krumlov 3 \\ a Krumlovský les jako další př́íklad multidepozitní \\ a sakrální krajiny
}

\author{
Middle Bronze Age metal hoard Moravský Krumlov 3 \\ and Krumlovský les as another example of a multi-deposition \\ and sacred landscape
}

\section{Milan Salaš}

\begin{abstract}
Abstrakt
Jeden z mála kovových depotů střední doby bronzové na Moravě byl objeven v r. 2013 v jižní části Krumlovského lesa na katastru Moravského Krumlova. V návaznosti na další depoty tohoto katastru je označen jako Moravský Krumlov 3. Jeho obsah (44 ks) tvoří vedle typologicky neklasifikovatelných zlomků nástroje (sekerky, srpy), šperky (spirálovitý náramek, jehlice, spirálovitá trubička, terčovitý závěsek) a výrobní složky, především zlomky slitků. Chronologicky citlivé taxony celek spolehlivě datují do staršího stupně středodunajské mohylové kultury (stupeň B B1, horizont depotů HodonínPř́tluky). Do tohoto stupně zatím na Moravě spadalo pět depotů, které se soustředily kolem dolních toků Moravy a Dyje, depot Moravský Krumlov 3 je nejsevernější a podobně jako v ostatních depotech tohoto horizontu se i v něm projevují karpatské vlivy. Vzhledem k ostatním lokálním nálezům kovových depozit starší i střední doby bronzové představuje jižní část Krumlovského lesa další př́klad depozitního areálu v periferní, neagrární oikumeně s makrokumulací poly- i monodepozit. Atributu těchto depozitních areálů jako možnému indikátoru sakrální krajiny nasvědčuje v Krumlovském lese také soudobá těžba místního rohovce, interpretovaná jako davová nesubsistenční aktivita transcendentálního významu.
\end{abstract}

\section{Klíčová slova}

Jižní Morava, Krumlovský les, střední doba bronzová, kovové depoty, depozitní areály, sakrální krajina

\begin{abstract}
One of the few Middle Bronze Age metal hoards in Moravia was found in the southern part of Krumlovský les (Krumlov Forest) in the cadastral district of Moravský Krumlov in 2013. Following the other hoards from this cadastral territory, it is numbered Moravský Krumlov 3. The hoard (44 items) contained apart from typologically unclassifiable fragments also tools (axes, sickles), jewellery (arm spiral, pin, spiral tube, discoid pendant) and production components, above copper ingots. The chronologically sensitive items date the hoard reliably to the early stage of the Middle Danube Tumulus Culture (stage B B1, horizon of hoards Hodonín-Prítluky). Until now, we knew of five hoards
\end{abstract}


from Moravia that fall within this chronological stage. They were concentrated along the lower reaches of the rivers Morava and Dyje. Moravský Krumlov 3 is the northernmost among the hoards of this horizon, which all exhibit Carpathian influences. With regard to other local finds of Early and Middle Bronze Age metal hoards, the southern part of Krumlovský les represents another example of a deposition area in a peripheral non-agrarian ecumene with macro-accumulation of poly- and mono-deposits. The possibility that this deposition area in Krumlovský les might be an indicator of sacred landscape is also corroborated by the contemporaneous extraction of local chert, which has been interpreted as a mass non-subsistence activity with transcendental significance.

\section{Key words}

South Moravia, Krumlovský les, Middle Bronze Age, metal hoards, deposition areas, sacred landscape

\section{1. Úvod}

Z množství snad až několika set kovových depotů doby bronzové, objevených (a případně zase zmizelých či nezvěstných) na Moravě za posledních zhruba dvacet let téměř vždy při amatérské detektorové prospekci, se jich podařilo nějakým způsobem odborně podchytit zhruba na 150 (srov. Salaš et al. 2020, 27; Salaš - Jarưšsová 2017). Je téměř s podivem, že drtivá většina zachycených depotů spadá do doby popelnicových polí, zatímco depoty starší a střední doby bronzové jsou výjimečné, což kontrastuje např. se situací v jižních Čechách (Chvojka - John Šálková 2015 s další lit.). Autorovi příspěvku jsou známy pouze tři takto objevené depoty únětické kultury (z toho dva publikované: $K a$ lábek 2013; Salaš 2015) a dva nepublikované depoty středodunajské mohylové kultury (SMK) s tím, že třetí potenciální depot může spadat do závěru střední nebo počátku mladší doby bronzové (Vich 2020).

$\mathrm{V}$ rámci tohoto minima staro- a středobronzových kovových depozit sehrává podstatnou úlohu specifický krajinný útvar Krumlovského lesa (obr. 1), tvořící severní část Leskounské vrchoviny a náležející jako geomorfologický okrsek do Bobravské vrchoviny (Bina - Demek 2012, 102-103). Zde byla v letech 2012-2015 při amatérských detektorových průzkumech objevena kromě solitérních bronzových artefaktů také tři kovová multidepozita, soustředěná v jižní části Krumlovského lesa mezi kótami 348 a 391 v jihovýchodní části katastru Moravský Krumlov (okr. Znojmo). Z tohoto katastru byl z celé doby bronzové dosud znám pouze jediný metalický depot, a to depot únětické kultury, objevený v r. 1931 v místní části Rakšice v poloze Pazderna (Ondráček 1959, 40; Salaš 2009, 20-21; Tihelka 1965, 23), který s ohledem na nové nálezy budeme evidovat jako Moravský Krumlov 1. Další tři nově objevené depoty budou tedy značeny jako Moravský Krumlov 2-4, přičemž Moravský Krumlov 2 náleží rovněž únětické kultuře a zbývající 3-4 středodunajské mohylové kultuře (obr. 2). Připomenout je třeba rovněž nejméně dva únětické depoty $\mathrm{z}$ výšinné a později opevněné polohy Leskoun (Tihelka 1965, 26), tedy depoty Olbramovice 1 a 2, vzdálené od jižní části Krumlovského lesa obdobně jako depot Moravský Krumlov 1, tedy cca 2 km. $\mathrm{V}$ předloženém př́spěvku bude $\mathrm{s}$ ohledem na jeho limitovaný rozsah prezentován a vyhodnocen depot s označením Moravský Krumlov 3. 


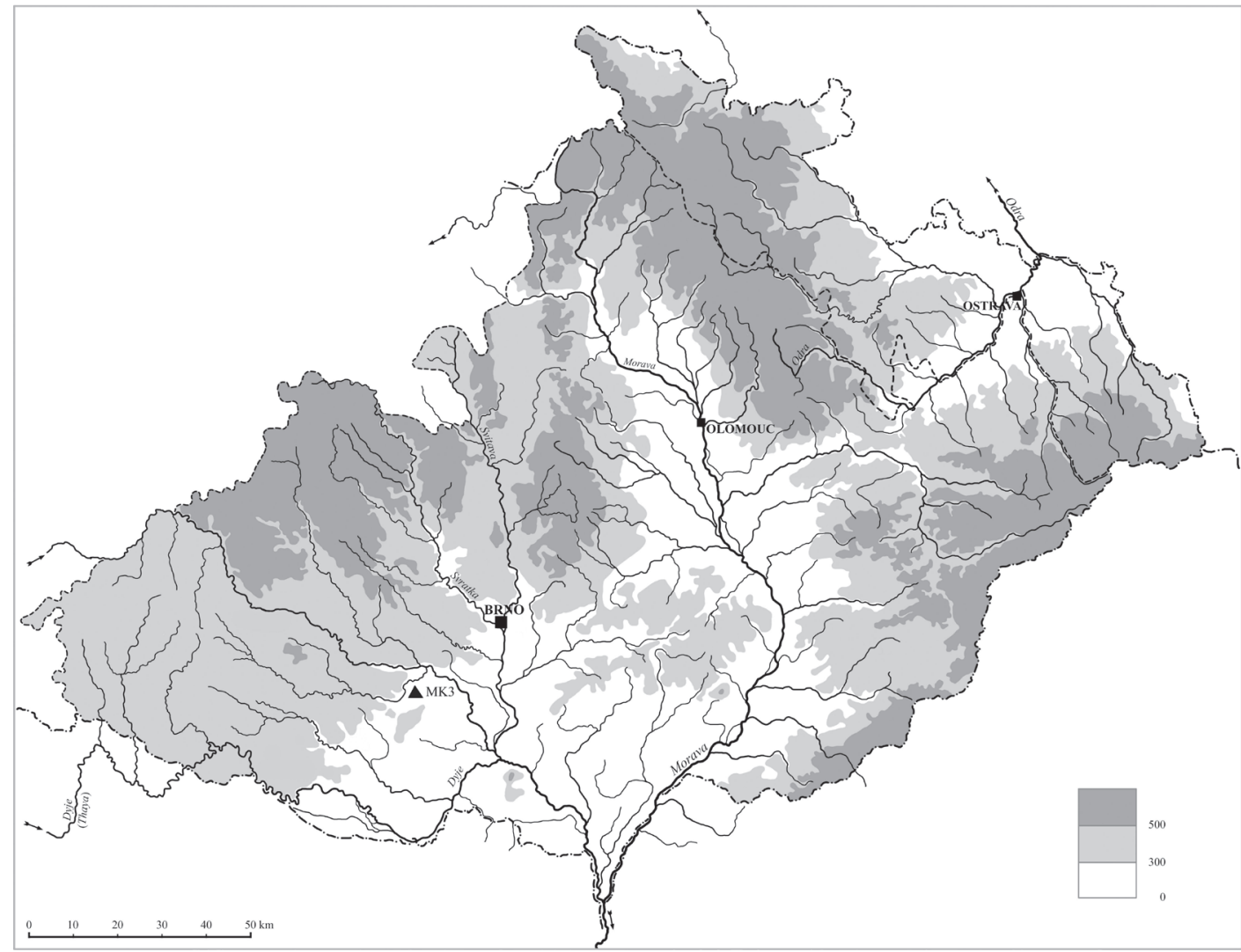

Obr. 1. Mapa Moravy s polohou nálezu kovového depotu Moravský Krumlov 3.

Fig. 1. Map of Moravia with the location of the metal hoard Moravský Krumlov 3.

\section{Topografická a nálezová situace depotu}

Depot objevil 16. 6. 2013 při povrchovém detektorovém průzkumu O. Kř́ž z Rosic v jihovýchodní části parcely č. $4120 .{ }^{1}$ Zde byl depot uložen v nadm. výšce 333 m na mírném SZ svahu kóty 339 (obr. 3), vzdálený od ní asi $80 \mathrm{~m}$ severozápadním směrem. Severním až severovýchodním směrem terén postupně spadá do úžlabiny s bezejmenným vodním tokem, vzdáleným od depotu cca $130 \mathrm{~m}$ a pramenícím výše po svahu z pưvodního močáloviště, dnes rybníčku (obr. 4). Samotný depot byl uložen ve shluku v hloubce 15-20 cm ve štěrkopískovém podloží a pod kamenem - přirozeným, neopracovaným kusem místního granodioritu (obr. 5), jehož horní část se nacházela těsně pod povrchem.

\section{Inventáŕ depotu}

\section{Sekerky}

1. Sekerka s oblým schůdkem, přecházejícím do týlové partie v postranní lišty, které se postupně snižují a u šikmo rovného a poněkud nepravidelného týlu vytrácejí, tělo pod schůdkem fasetovitě tvarováno do osmihranu, široce vějířovitě rozšířený břit uprostřed se 


\begin{tabular}{|l|l|l|c|l|c|c|}
\hline Katastrální území & Poloha & $\begin{array}{l}\text { Druh } \\
\text { a označení }\end{array}$ & $\begin{array}{c}\text { Rok } \\
\text { nálezu }\end{array}$ & Obsah & Kultura & Datování \\
\hline Moravský Krumlov & $\begin{array}{l}\text { Rakšice: } \\
\text { Pazderna }\end{array}$ & Depot: MK 1 & 1931 & $\begin{array}{l}3 \text { spirál. náramky, } \\
2 \text { kruh. hřivny }\end{array}$ & ÚK & B A2 \\
\hline Moravský Krumlov & Krumlovský les & Depot: MK 2 & 2012 & 16 kruh. hřiven & ÚK & B A2 \\
\hline Ivančice & Réna & Solitérní bronz & 2012 & část sekerky & ÚK & B A2 \\
\hline Moravský Krumlov & Krumlovský les & Depot: MK 3 & 2013 & zlomkový depot & SMK & B B1 \\
\hline Moravský Krumlov & Krumlovský les & Solitérní bronz & 2015 & srp s trnem & SMK & B B1 \\
\hline Moravský Krumlov & Krumlovský les & Depot: MK 4 & 2014 & $\begin{array}{l}2 \text { masivní C } \\
\text { náramky }\end{array}$ & SMK & B C2 \\
\hline Moravský Krumlov & Krumlovský les & Solitérní bronz & 2014 & $\begin{array}{l}\text { masivní C } \\
\text { náramek }\end{array}$ & SMK & B C2 \\
\hline
\end{tabular}

Obr. 2. Přehled kovových depozit starší a střední doby bronzové v areálu Krumlovského lesa a jeho nejbližším okolí (srov. obr. 10). Publikovány pouze depoty Moravský Krumlov 1 a Vedrovice 1 (Salaš 2005, 284-285; 2009, 20-21; Tihelka 1965, 23). MK - Moravský Krumlov, ÚK - únětická kultura, SMK - středodunajská mohylová kultura.

Fig. 2. An overview of Early and Middle Bronze Age metal hoards in the area of Krumlovský les and in its close neighbourhood (cf. Fig. 10). The only published hoards are Moravský Krumlov 1 and Vedrovice 1 (Salaš 2005, 284-285; 2009, 20-21; Tihelka 1965, 23). MK - Moravský Krumlov, ÚK - Únětice Culture, SMK - Middle Danube Tumulus Culture.

zpatinovaným výlomem, po stranách lehce odrcený. - D. $174 \mathrm{~mm}$, š. břitu $57 \mathrm{~mm}$, profil přes schůdek $26 \times 20 \mathrm{~mm}$, hmot. 298 g. - Obr. 6: 1 .

2. V týlové části rozlomená sekerka s oblým schůdkem, přecházejícím do týlové partie v postranní lišty, týl s asymetricky klínovým výřezem, tělo pod schůdkem fasetovitě tvarováno do osmihranu, široce vějířrovitě rozširřrená břitová partie s náznakem obloukovité fasety paralelní s ostrým břitem, lom zpatinovaný. D. $142 \mathrm{~mm}$, š. břitu $38 \mathrm{~mm}$, profil přes schůdek $18 \times 22$ mm, hmot. 148 g. - Obr. 6: 2 .

3. Týlová partie sekerky s nízkými postranními lištami, rovně a mírně šikmo zakončeným týlem, lom zpatinovaný. - D. $68 \mathrm{~mm}$, profil max. $30 \times 16 \mathrm{~mm}$, hmot. 125 g. - Obr. 6: 3 .

\section{Srpy}

4. Týlová partie srpu s hřbetním a paralelně na čepeli také vnitřním žebrem, týl prostý rovný, nepravidelně zesílený na přední plochu a se zahroceným nálitkem na hřbetní hraně, uprostřed čepele před týlem slabě kónický až polokulovitý výčnělek, břitová část před týlem tupá, lom zpatinovaný. - D. 38 mm, š. čepele 24 mm, hmot. 19,7 g. - Obr. 6: 4.

5. Pravá část druhotně upravené(?) srpové čepele s klínovitou profilací, směrem $\mathrm{k}$ jednostranně zesílenému týlu jinak ostrý a lehce odrcený břit schodkovitě odsazený a otupený, na hřbetě před zesíleným a rovným týlem zásek, lom zpatinovaný. - D. $87 \mathrm{~mm}$, š. max. $26 \mathrm{~mm}$, hmot. 42 g. - Obr. 6: 5. 


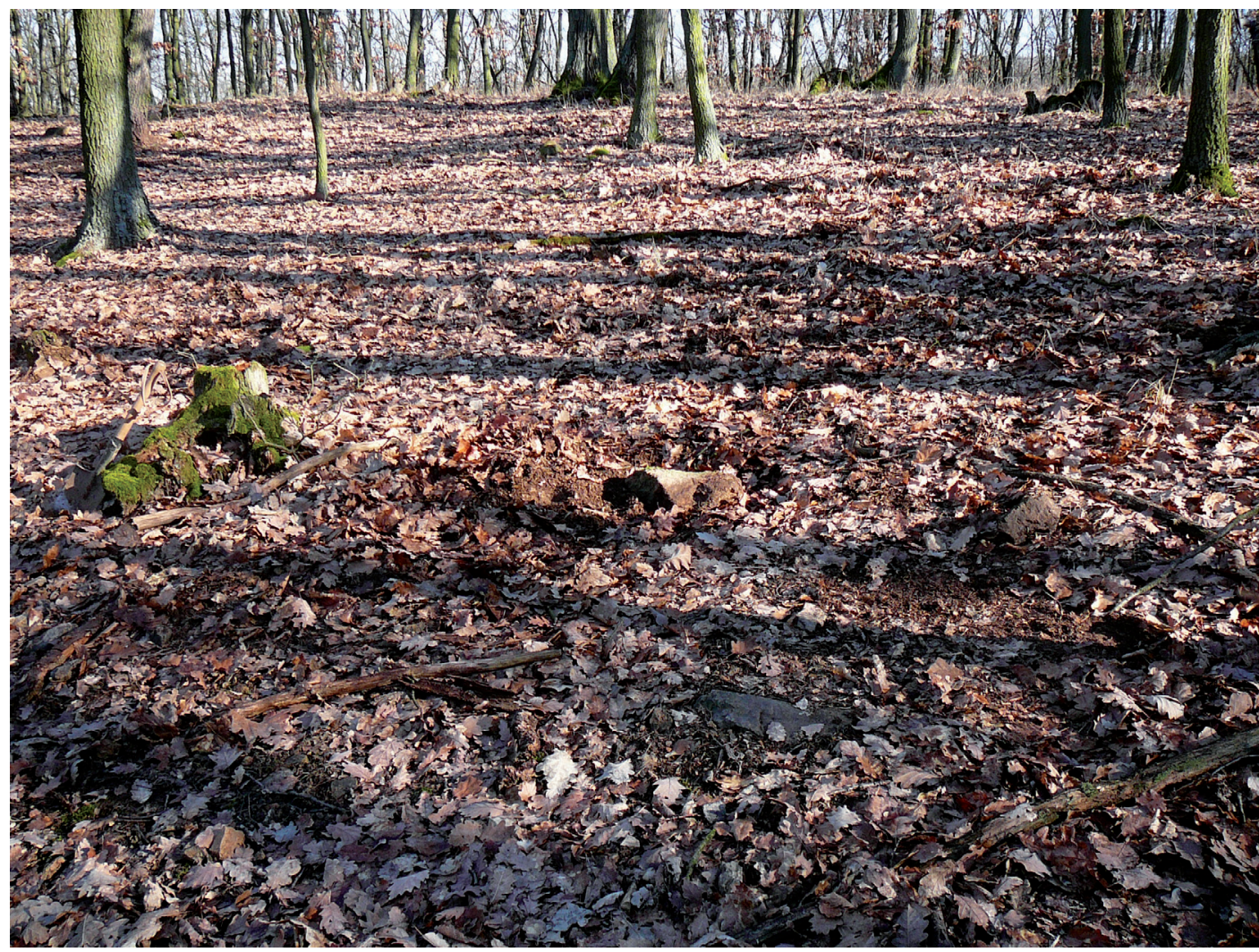

Obr. 3. Poloha s místem nálezu depotu Moravský Krumlov 3, uloženého pod kamenem. Pohled od JZ. Foto M. Salaš.

Fig. 3. The location of the findspot of the hoard Moravský Krumlov 3, deposited under a stone. A view from SW. Photo M. Salaš.

\section{Kruhový šperk rukou}

6. Spirálovitý náramek tvořený třemi závity z pásku s hladkým středovým žebrem, u konců pásek přechází v tyčinku kruhového profilu, která je stočená do nestejně velkých spirálovitých růžic, pásek je zdobený liniemi vybíjených bodů, tvořících podél středového žebra $\mathrm{z}$ jedné strany př́mou linii, z druhé strany vlnovku, vnější okraj pásku u konce s menší růžicí odrcený. - D. přes růžice $99 \mathrm{~mm}$, průměr těla spirály $93 \mathrm{~mm}$, pásek $12 \times 3 \mathrm{~mm}$, hmot. 129 g. - Obr. 6: 6.

\section{Jehlice}

7. Odlomená a vlnovitě tvarovaná, v profilu rozetovitá jehla jehlice, patrně typu s otvorem v zesíleném krčku, lom zpatinovaný. - D. $72 \mathrm{~mm}$, hmot. 3,8 g. - Obr. 6: 7.

\section{Závěsek}

8. Litý kruhový plochý a jednostranně profilovaný terčík, obvod na dorsální straně zesílen hladkým žebírkem, uprostřed kónický knoflík, pole mezi knoflíkem a zesíleným okrajem bohatě zdobeno jemnou rytou a vybíjenou výzdobou podél obvodu drobné vybíjené body lemované 


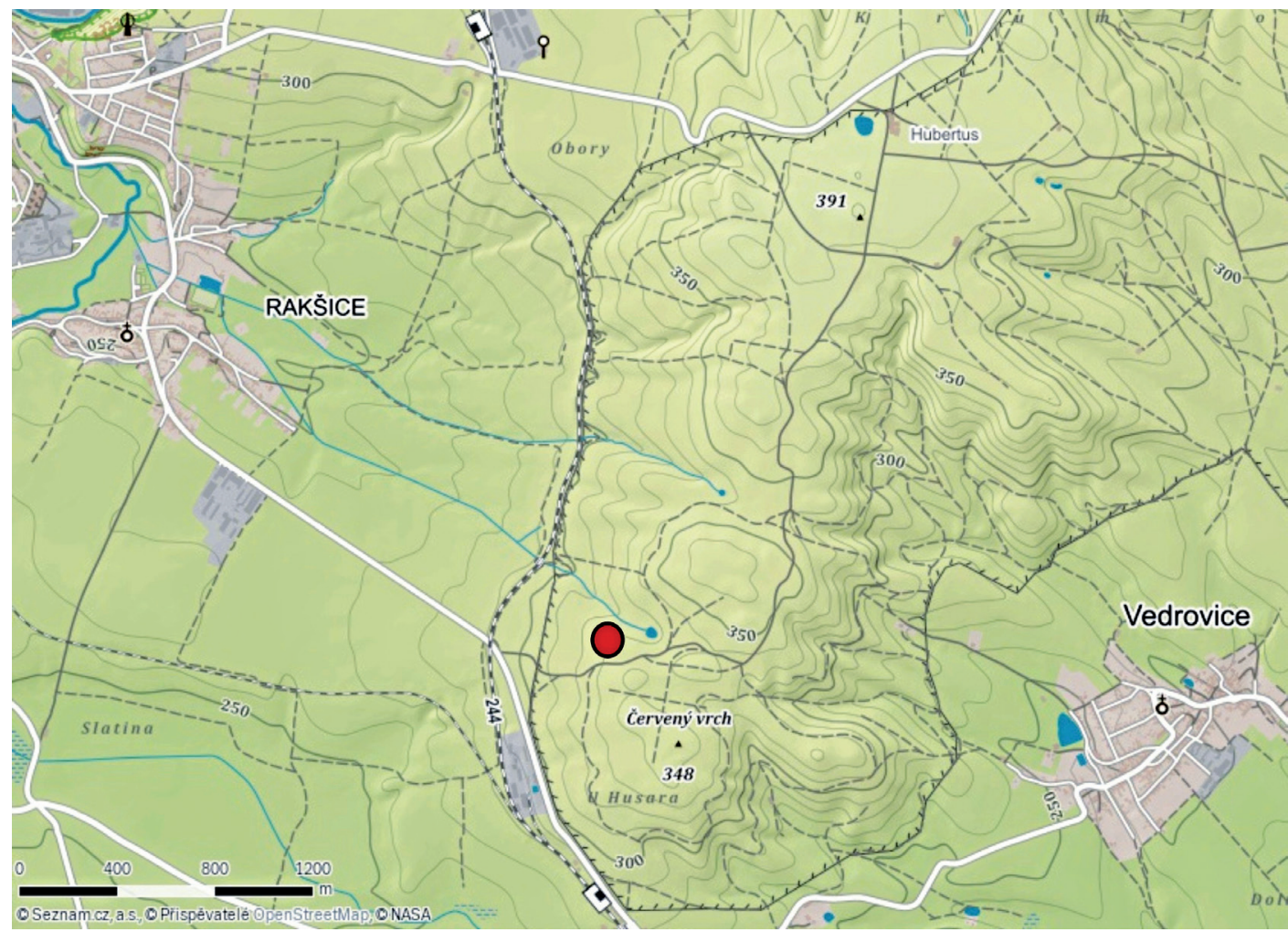

Obr. 4. Poloha s místem nálezu depotu Moravský Krumlov 3. Mapový podklad: www.mapy.cz.

Fig. 4. The location of the findspot of the hoard Moravský Krumlov 3. Map source: www.mapy.cz.

z vnitřní strany dvěma koncentrickými rýhami, obdobně kolem knoflíku dvě koncentrické rýhy vně lemované řadou vybíjených bodů, uprostřed terče ryté girlandy, v zavěšených čárkách zakončené vybíjeným bodem a vně lemované dvěma paralelními obloukovitými rýžkami. V jednom bodě při obvodu oválný otvor po vzduchové bublině, ventrální plocha terčíku zcela hladká. - Prům. 50 mm, v. 4 mm, hmot. 21,9 g. - Obr. 6: 8; 7.

\section{Spirálovitá trubička}

9. Spirálovitá trubička ze silnějšího drátu s mírně zploštělou vnější stranou, jeden konec přirozený, tupě zahrocený, druhý odlomený se zpatinovaným lomem. - D. 91 mm, hmot. 11 g. - Obr. 6: 9 .

\section{Neklasifikovatelné artefakty}

10. Plechový artefakt (šperk?) obdélníkovitého tvaru s jedním užším koncem stočeným na bazální stranu do trubičky, druhý konec odlomený, podélné strany více či méně přehnuty na zadní plochu, na lícní ploše dvě podélné paralelní řady drobných pukliček, vybíjených ze zadní plochy, jinak ušlechtilá patina přes vnější stranu diagonálně odprýsknutá. - D. $31 \mathrm{~mm}$, š. max. 25 mm, hmot. 3,2 g. - Obr. 6: 10.

11. Částečně ohnutý a překroucený zlomek tyčinky kvadratického profilu, lomy zpatinovány. - D. $36 \mathrm{~mm}$, profil $8 \times 8 \mathrm{~mm}$, hmot. 13,9 g. Obr. 6: 11 . 


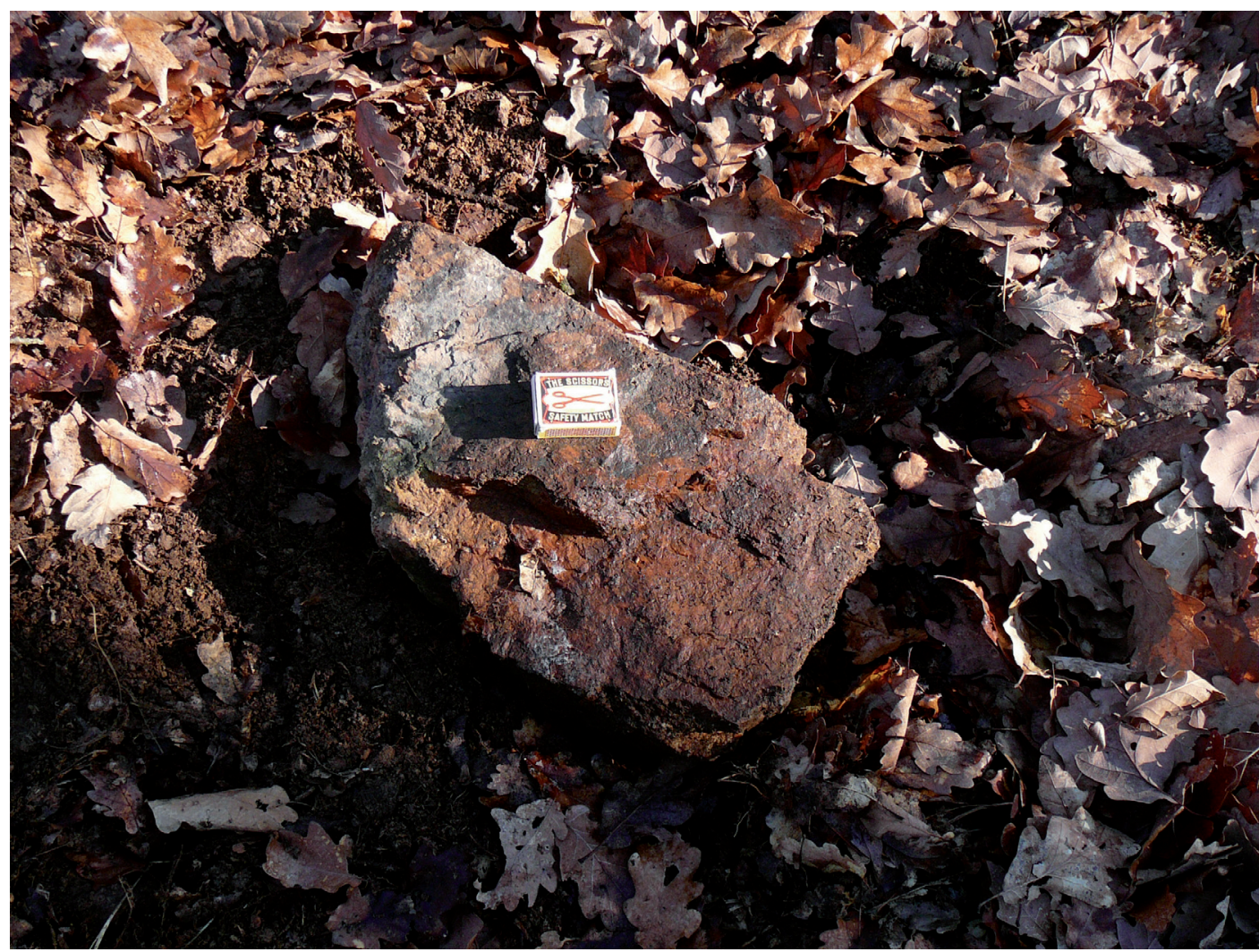

Obr. 5. Kámen - granodiorit, pod kterým byl pưvodně uložený depot Moravský Krumlov 3. Foto M. Salaš.

Fig. 5. The stone - granodiorite, under which the hoard Moravský Krumlov 3 was originally deposited. Photo M. Salaš.

12. Plochý obdélníkovitý odlitek (tyčinkovitý ingot?) s ploše bikonvexním profilem a ostrými boky, jeden př́ićný konec oboustranně zkosený ostrý, druhý s nepravidelnou ploškou. - D. $57 \mathrm{~mm}$, profil $16 \times 5 \mathrm{~mm}$, hmot. 22 g. - Obr. 6: 12 .

13. Zlomek plochého odlitku, obvod tvořen zpatinovanými lomy. - $18 \times 15 \times 2 \mathrm{~mm}$, hmot. 2,6 g. - Obr. 6: 13.

14. Drobný zlomek plochého tenkého odlitku, na jedné ploše se dvěma drobnými trhlinami, obvod tvořen zpatinovanými lomy. - $17 \times 11 \times 2 \mathrm{~mm}$, hmot. 1,7 g. - Obr. 6: 14.
15. Drobná tyčinka pravidelného kruhového profilu, jeden konec rovně seříznutý, druhý pravidelně ostře zahrocený. - D. $21 \mathrm{~mm}$, průměr $2 \mathrm{~mm}$, hmot. 0,6 g. - Obr. 6: 15 .

16. Atypický odlitek pravoúhlého tvaru, po všech stranách přirozeně ukončený, užší část (z odlévací formy?) s pravidelnými hladkými plochami, kolmo navazující polovina (zátek mimo formu?) poněkud masivnější a členitější. - $42 \times 31$ mm, hmot. 59 g. - Obr. 6: 16 . 


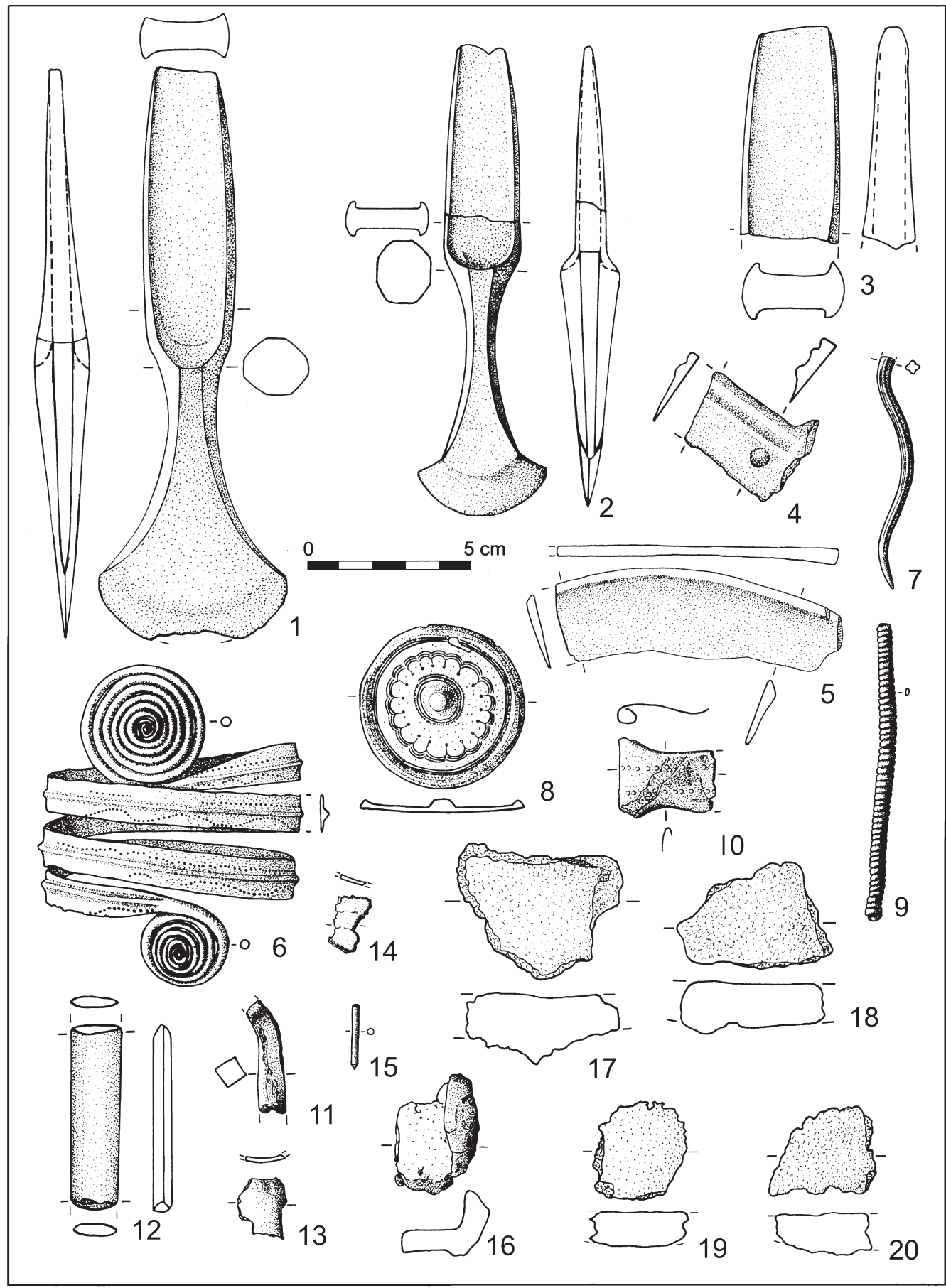

Obr. 6. Inventář depotu Moravský Krumlov 3. 24 slitků nevyobrazeno (také viz obr. 8). Kresba A. Vaníčková.

Fig. 6. Content of the hoard Moravský Krumlov 3. 24 pieces of copper ingots are not depicted (see also Fig. 8). Drawing A. Vaníčková. 


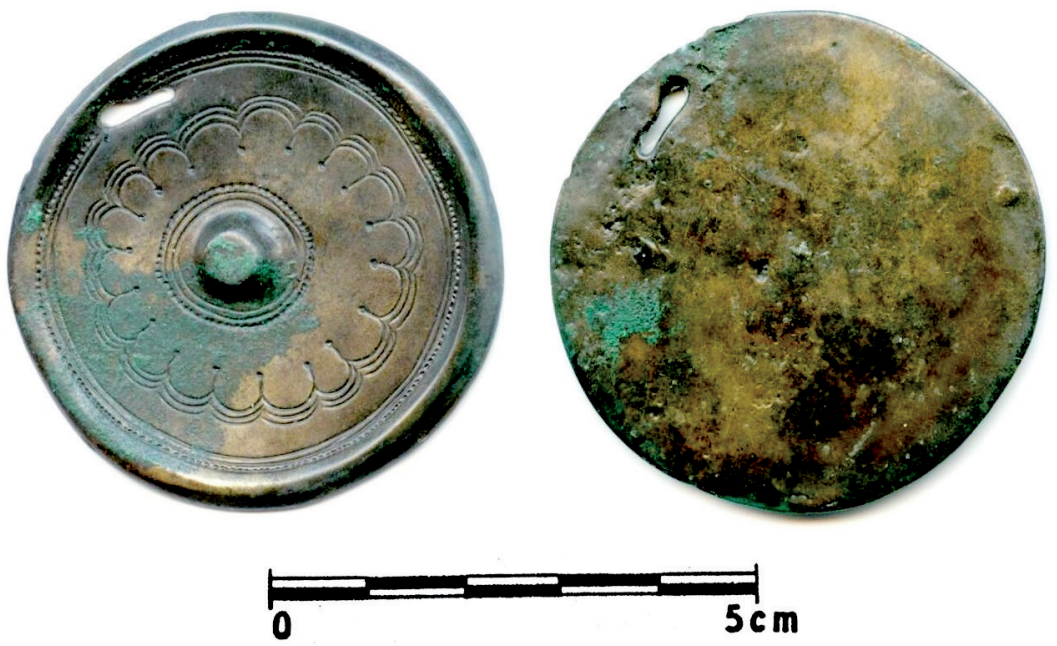

Obr. 7. Litý terčovitý závěsek v depotu Moravský Krumlov 3. Foto M. Salaš.

Fig. 7. Cast discoid pendant from the hoard Moravský Krumlov 3. Photo M. Salaš.

\section{Slitky (obr. 8)}

17. Středový zlomek těla slitku, horní plocha poměrně hladká a kompaktní, spodní nepravidelně členitá, lomy zpatinované s četnými staženinami. - $46 \times 42 \times 24$ mm, hmot. 100 g. - Obr. 6: 17 .

18. Středový zlomek těla slitku, horní plocha poměrně hladká a kompaktní, spodní nepravidelně členitá, lomy zpatinované se staženinami. - $41 \times 32 \times 15$ mm, hmot. 73 g. - Obr. 6: 18 .

19. Středový zlomek těla slitku, obě plochy hladké a kompaktní, lomy zpatinované bez staženin. - $31 \times 31 \times 11$ mm, hmot. 45 g. - Obr. 6: 19 .

20. Středový zlomek těla slitku, horní plocha hladká a kompaktní, spodní mírně klenutá, kompaktní, lomy zpatinované a téměř bez staženin. $-34 \times 27 \times 13$ mm, 49 g. - Obr. 6: 20 .

21. Středový zlomek těla slitku, horní plocha hladká a kompaktní, spodní členitá, zpatinované lomy se staženinami. $-25 \times 26 \times 10 \mathrm{~mm}$, hmot. $20 \mathrm{~g}$.
22.-26. Pět malých středových plochých zlomků těl slitků s jednou plochou hladkou a druhou drobně členitou, lomy zpatinované. - $26 \times 20 \times$ $10 \mathrm{~mm}$, hmot. $16 \mathrm{~g} ; 34 \times 15 \times 8 \mathrm{~mm}$, hmot. $11 \mathrm{~g}$; $23 \times 18 \times 8 \mathrm{~mm}$, hmot. $14 \mathrm{~g} ; 25 \times 17 \times 8 \mathrm{~mm}$, hmot. $11 \mathrm{~g} ; 24 \times 18 \times 10 \mathrm{~mm}$, hmot. $13 \mathrm{~g}$.

27.-30. Čtyři drobné středové zlomky těl slitků, lomy zpatinované a většinou se staženinami. $21 \times 13 \times 9 \mathrm{~mm}$, hmot. $8 \mathrm{~g} ; 15 \times 11 \times 7 \mathrm{~mm}$, hmot. 3,6 g; $12 \times 11 \times 7 \mathrm{~mm}$, hmot. $2,9 \mathrm{~g} ; 11 \times$ $9 \times 10 \mathrm{~mm}$, hmot. $2,3 \mathrm{~g}$.

31. Polovina malého oválného slitku s kompaktními plochami, horní hladkou rovnou, spodní klenutou, zpatinovaný lom bez staženin. $-34 \times$ $24 \times 10 \mathrm{~mm}$, hmot. $27 \mathrm{~g}$.

32. Okrajový zlomek těla slitku s jednou plochou kompaktní a klenutou, druhou nepravidelně členitou, zpatinované lomy bez staženin. $-42 \times 29 \times 15 \mathrm{~mm}$, hmot. 45,5 g. 


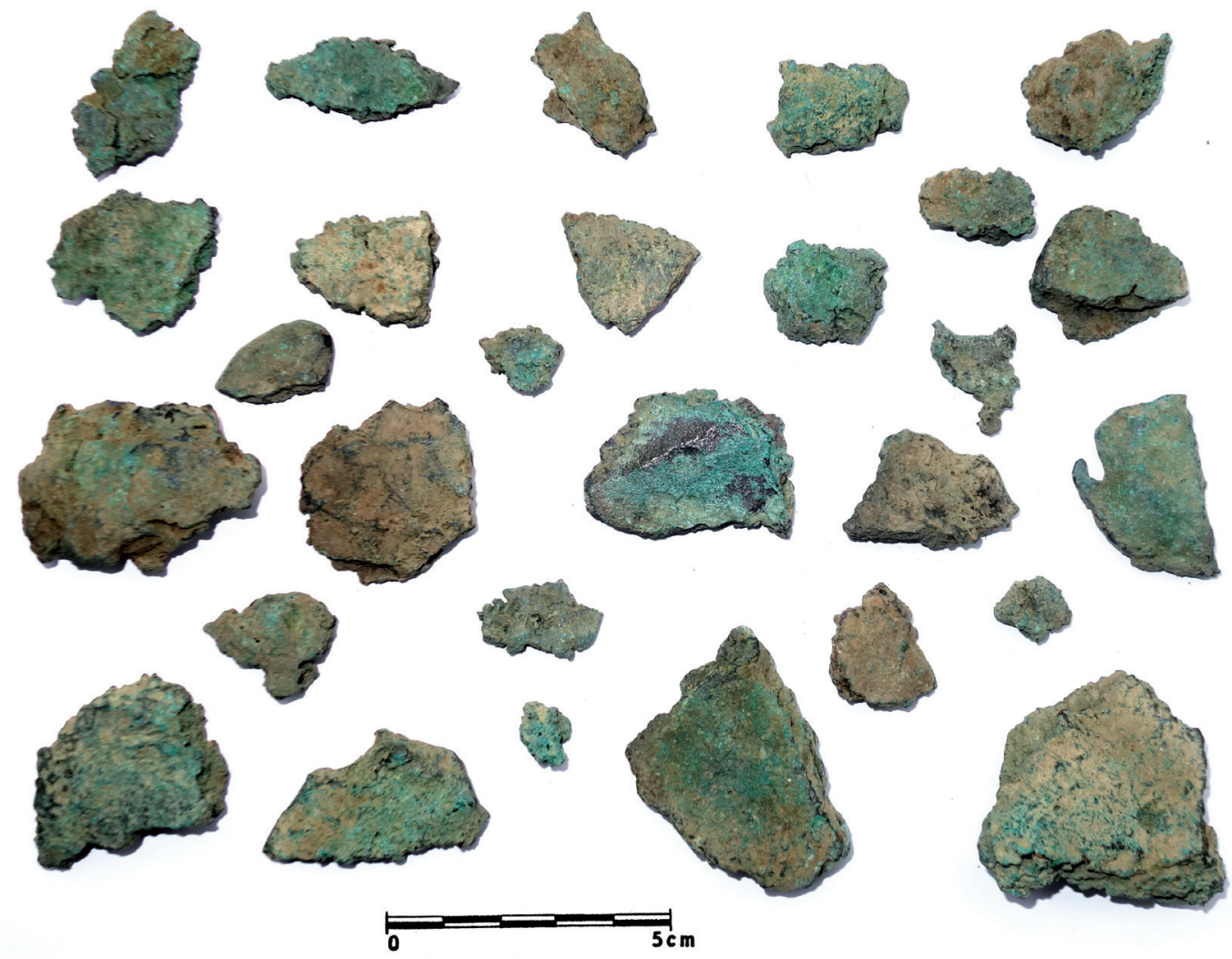

Obr. 8. Slitky v depotu Moravský Krumlov 3. Foto M. Salaš.

Fig. 8. Copper ingots in the hoard Moravský Krumlov 3. Photo M. Salaš.

33. Okrajový zlomek plochého těla slitku s při- 36. Okrajový zlomek těla slitku s kompaktními bližně paralelními kompaktními plochami, a téměř paralelními plochami, zpatinovaný lom zpatinovaný lom s ojedinělými staženinami. - s ojedinělými staženinami. - $27 \times 20 \times 12$ mm, $40 \times 24 \times 8 \mathrm{~mm}$, hmot. $26 \mathrm{~g}$. hmot. $25 \mathrm{~g}$.

34. Okrajový zlomek plochého těla slitku s při- 37. Okrajový zlomek plochého těla slitku s přibližbližně paralelními kompaktními plochami, zpa- ně paralelními kompaktními plochami, zpatinovatinovaný lom bez staženin. $-37 \times 37 \times 9$ mm, nýlom bez staženin. $-25 \times 20 \times 8$ mm, hmot. 16 g. hmot. $34 \mathrm{~g}$.

35. Okrajový zlomek těla slitku s mírně členitou horní vodorovnou plochou a mírně členitou spodní kónickou plochou, zpatinovaný lom bez staženin. $-28 \times 24 \times 11 \mathrm{~mm}$, hmot. $21 \mathrm{~g}$.

38. Okrajový zlomek plochého těla slitku, plochy hladké kompaktní, zpatinované lomy s ojedinělými staženinami. - $25 \times 16 \times 8 \mathrm{~mm}$, hmot. $14 \mathrm{~g}$. 39. Okrajový zlomek drobného oválného slitku(?) s paralelními, kompaktními a hladkmi 
plochami, zpatinovaný lom bez staženin. $-21 \times$ $16 \times 7 \mathrm{~mm}$, hmot. $9 \mathrm{~g}$.

40.-42. Tři drobné nepravidelné okrajové zlomky slitků se staženinami, lomy zpatinované. - 31 $\times 18 \times 9 \mathrm{~mm}$, hmot. $12 \mathrm{~g} ; 24 \times 24 \times 11 \mathrm{~mm}$, hmot. $16 \mathrm{~g} ; 23 \times 18 \times 9 \mathrm{~mm}$, hmot. $10 \mathrm{~g}$.

43.-44. Dva drobné ploché nepravidelné okrajové zlomky slitků, lomy zpatinované. $-21 \times 14$ $\times 5 \mathrm{~mm}$, hmot. $4 \mathrm{~g}$; $20 \times 16 \times 5 \mathrm{~mm}$, hmot. $3 \mathrm{~g}$.

\section{Analýza obsahu depotu}

Depot Moravský Krumlov 3 se 44 artefakty lze považovat za spolehlivý nálezový celek s kompletním původním inventářem. Složením představuje zlomkový heterogenní depot, kde jsou kromě slitků zastoupeny nástroje a šperky.

\subsection{Sekerky}

Ze tři sekerek nelze přesněji typologicky klasifikovat solitérní odlomenou týlovou partii s náznakem postranních lišt (obr. 6: 3). Zcela dochovaná a kompletní sekerka č. 1 náleží tvarům se schůdkem, který se konvergentně sbíhá z postranních lišt a je rovně ukončený, čímž v typologické klasifikaci J. Říhovského plně odpovídá jeho sedmé skupině (Říhovský 1992, 127-128). Dobře s tím koresponduje také fasetovaná, osmihranná břitová partie a výrazně vějířovitý, až obloukovitý břit. Tento taxon byl na Moravě dosud zastoupen pouze čtyřmi exempláři (pátý s nejistou lokalizací), bohužel představujícími ojedinělé nálezy (Ǩihouský 1992, 127-128). Depot Moravský Krumlov 3 je tak vůbec první nálezový celek s tímto taxonem a doplňuje jejich geografický výskyt na jižní Moravě v okresech Znojmo, Břeclav a Vyškov. Mimo jižní Moravu se sekerky sedmé skupiny vyskytují naprosto výjimečně (Řihouský 1992, 128), takže je lze v tom- to prostoru považovat za autochtonní taxon. $\mathrm{Na}$ základě typologické afinity se sekerkami se srdcovitým nebo zaobleným lištovitým schůdkem jsou sekerky se schůdkem sedmé skupiny spojovány se starším stupněm SMK (Řihovský 1992, 128).

Druhá sekerka náleží podle zaobleného lištovitého schůdku (obr. 6: 2) v typologickém systému J. Říhovského páté skupině sekerek se schůdkem (Řihouský 1992, 124-126). Podobně jako první sekerka i tato se vyznačuje výrazně projmutou, fasetovanou břitovou partií a široce vějiřrovitým břitem. Pátou skupinu těchto sekerek zatím na Moravě reprezentovalo pět lokalizovaných exemplářu, ale pouze jeden pochází z nálezového celku - z depotu v Hodoníně (Říhouský 1992, 124; Salaš 2005, 32-33). Tím je také tento taxon datovaný rovněž do staršího mohylového stupně a depotového horizontu Hodonín-Přítluky (Ǩihovský 1992, 125; Salaš 2005, 132-133). Na rozdíl od sekerek sedmé skupiny mají sekerky páté skupiny poměrně širší geografický rozptyl (Ǩihouský 1992, 126), v Bavorsku jsou ovšem jejich nepočetné a ojedinělé nálezy v rámci sekerek $\mathrm{s}$ př́ímým nebo zaobleným schůdkem datovány do středního až mladšího mohylového stupně (Pászthory - Mayer 1998, 89).

\subsection{Srpy}

Srpy jsou v depotu zastoupeny dvěma zlomky, které však pro fragmentární stav nelze přesněji typologicky klasifikovat. Z prvního, původní velikostí menšího srpu je dochována pouze rovně ukončená týlová partie, hřbetní žebro těsně na čepeli kopíruje i žebro vnitřní (obr. 6: 4). Poněkud atypický je zde lehce kónický, až bradavkovitý výčnělek, a to jak drobným tvarem, tak umístěním uprostřed týlové partie až pod úrovní vnitřního žebra. Pokud se týká umístění trnu na srpech střední až počátku 
mladší doby bronzové, pak solitérní výčnělky uprostřed týlu, a to spíše větší až oválné, jsou méně frekventované než výčnělky ve hřbetní části týlu, drobnější kolmé kuželovité uprostřed týlu jsou pak ještě vzácnější (např. depoty Senomaty: Smejtek 2015, 584, tab. 2: 10; Bühl, Ackenbach: Rittershofer 1983, 201, Abb. 35: 13-15; 39 : $3,8,9)$. Podobnou dispozici vykazují i některé mladší srpy (např. Kroměříž: Řihouský 1989, Taf. 3: 29, 30; Salaš 2005, 349-350), zde se však jedná už o větší, delší tvary. Menší srpy pouze se hřbetním žebrem s touto pozicí kuželovitého trnu dobře odpovídají široce rozšířenému typu Friedberg a její variantě A s obecným datováním do staršího mohylového stupně (Primas 1986, 51-52, 59-60).

U zlomku v Moravském Krumlově 3 je z morfotypologického hlediska podstatná přítomnost také vnitřního žebra. Vnitřní žebra na srpech s trnem v naprosté většině ale nebývají dotažena až k samotnému týlu, jako je tomu $\mathrm{v}$ tomto př́ípadě a trn zpravidla bývá umístěn v úrovni vnitřního žebra, popř. přímo proti němu. V typologii $M$. Primasové by zlomek v analyzovaném depotu odpovídal typu Grenchen, kde trn je usazen ještě na čepeli, většinou ale bývá oválný (Primas 1986, 54-55). V moravském prostředí mohou být příkladem takové dispozice vnitřního žebra a kolmého, víceméně kuželovitého trnu dva srpy ve staromohylovém depotu Př́tluky 1 (Ǩíhovský 1989, Taf. 1: 4, 5; Salaš 2005, 280) nebo v mladším depotu z Kubšic, zde je ale trn až na samotném týlu (Říhovský 1989, Taf. 3: 27; 4: 49; Salaš 2005, 276-279). Umístění solitérního výčnělku pod úrovní vnitřního žebra je na zlomku v krumlovském depotu poměrně unikátní, případné a jen přibližně srovnatelně koncipované exempláře jsou vzácné (např. Gedl 1995, Taf. 11: 173; Mozsolics 1967, Taf. 54: 4, 8, 10; Primas 1986, Taf. 4: 67; 12: 192). Z moravských celků nalezneme umístění trnu pod úrovní vnitřního žebra na dvou srpech v Hodoníně, přičemž na jednom je vnitřní žebro rovněž protaženo až k týlové ploše (Řihovský 1989, Taf. 1: 1; 5: 62; Salaš 2005, 262-263). Jinak ale ani tyto paralely nejsou zcela dokonalé, protože trny zde mají oválný tvar. Pokud některé z citovaných analogií jsou v datovaných celcích (Ackenbach: Rittershofer 1983; Hodonín: Salaš 2005, 132-135; Uzd: Mozsolics 1967, 174), spadají rovněž do počátečního stupně střední doby bronzové, tedy do Reineckova stupně B B1 či karpatského horizontu Kosziderpadlás.

Typologicky zcela neklasifikovatelná je část srpové čepele (obr. 6: 5), která je zřejmě výsledkem reparační úpravy přebroušením lomové plochy poté, co došlo k odlomení týlové části. Vzhledem k následné absenci úchytné části ale reutilizovaný artefakt již nemohl být použiván jako srp.

\subsection{Náramek}

Spirálovitý náramek (obr. 6: 6) patří do velké skupiny plochých, většinou plechových spirálovitých šperků paží a nohou, kde plechový pás bývá zesílen středovým žebrem a ke koncům se pás zužuje do tyčinky kruhového profilu, stočenou do koncových spirálovitých růžic. Podle tvaru pásku lze ještě rozlišit dvě podskupiny, kde první má prosté okraje pásku a výzdobu pouze z vybíjených bodů, u druhé bývají okraje pásku zesíleny a výzdobnou kompozici doplňují pukličky. Mezi oběma podskupinami je výrazný chronologický rozdíl, zatímco první je spojována se starším mohylovým stupněm, mladší vystupuje až v depotech mladšího až pozdně mohylového stupně, resp. v depotech horizontu Hradisko-Hulín, případně i později (depot Mankovice: Salaš 2005, 100-101; Stuchlik 1981, 362-363). Zatím jediným zástupcem první podskupiny byly na Moravě části plechových spirál z depotu Mušov 1 (Stuchlik 1981, 361-363, obr. 2: 5, 7, 10). Geograficky další nejbližší paralelou, a to jak tvarem, tak výzdobou, mohou být 
zlomky přepálené a deformované spirály z hrobu 22 na dolnorakouském pohřebišti v Pitten (Hampl - Kerchler - Benkovsky-Pivovarová 1981, 30, Taf. 203:1; Benkovsky-Pivovarová 1985, 61).

Oproti náramku v depotu Moravský Krumlov 3 je většina ostatních exemplářu této podskupiny ze širších plechových pásků a většinou také s vyšším počtem závitů, jinak jsou ale morfologicky i výzdobou identické a není důvod je typologicky rozlišovat. Celkově tento spirálovitý šperk rukou, popř. nohou, představuje jak chorologicky, tak chronologicky poměrně citlivý taxon. Provenienčně totiž reprezentuje především vnitrokarpatský šperk příznačný pro kosziderský horizont a v podstatě tedy pro stupeň B B1 podle Reinecka (Salaš 2005, 100-101 s další lit). Můžeme proto jeho nálezy západně od Karpatské kotliny a karpatského oblouku včetně moravských posuzovat přinejmenším jako výsledek karpatských vlivů, případně přímo jako karpatské importy, které západním směrem pronikly podle Dunaje až do Bavorska (např. München-Pasing: David 2002, Taf. 219: 4).

\subsection{Jehlice}

Další kategorii šperku, již s praktickou funkcí spinadla, zastupuje jehlice, ze které je ale dochována pouze vlnovitě prohnutá jehla s kvadratickým, až rozetovitým profilem (obr. 6: 7). Takto profilované jehly se vyskytují u širokého společenství jehlic s otvorem v zesíleném krčku. Dále však při absenci krčku i hlavice nelze spolehlivě rozhodnout, jakému konkrétnějšímu typu by v typologickém třídění podle $\mathrm{J}$. Ř́íhovského (1979, 20-33) jehlice náležela. Rozetovitě profilované a někdy zvlněné jehly se objevují jak u typu s jednostranně zesíleným, tak u typu se symetricky zesíleným krčkem,

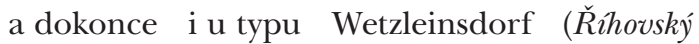
1979, Taf. 2: 24, 27; 3: 30, 31, 33, 38-40, 42, 44, 46; 4: 51, 59). V dosavadních depotech na
Moravě se zatím jehlice s takto profilovanou jehlou sice zatím nenalezla (srov. Salaš 2005, 105), nicméně v hrobových celcích mimo Moravu se takové exempláře běžně vyskytují (např. Sieding, Stratzing: Řihouský 1979, 21, 23, Taf. 2: 24-25; 3: 39; Enns: David 2002, Taf. 303: 5, 7; Wetzleinsdorf, München-Untermenzing: $D a-$ vid 2002, Taf. 316: 7, 8; 327: 9; Pitten: Hampl - Kerchler - Benkovsky-Pivovarová 1981, 205: 11; 218: 116-1, 2; 222: 1; 223: 12, 17; 225: 6; 226: 1; 229: 6; 230: 9, 15; David 2002, Taf. 321: 1, 6; Haid: Benkovsky-Pivovarová - Stadler 2019, 50, Abb. 3: 1; Majcichov: Benkovsky-Pivovarová - Chropouský 2015a, Taf. 53: 13-2; 57: 42-1; Novotná 1980, Taf. 8: 290; Iwanowice, Kietrz: Gedl 1983, Taf. 4: 102-105) a podle nich lze jehlice s rozetovitě profilovanou jehlou bez ohledu na tvar krčku i hlavice spolehlivě datovat do staršího mohylového stupně, čili Reineckova stupně B B1 (Benkovsky-Pivovarová 1985, 29-34; Benkovsky-Pivovarová - Chropouský 2015b, 56-57, vše se starší lit.). Přitom z chorologického hlediska - jak již také vyplývá z výčtu analogií - jsou tyto jehlice irelevantní, mají široký geografický rozptyl (̌̌ihouský 1979, 25-26, 29).

\subsection{Litý terčík}

Do kategorie šperků či ozdob můžeme zařadit také litý terčík, jehož lícní plocha je po obvodu zesílena hladkým žebírkem, opatřena středovým kónickým výčnělkem a bohatou rytou a vybíjenou výzdobou (obr. 6: 8; 7). Jeho základní typologicko-funkční klasifikace je poněkud sporná. Typologicky i chronologicky lze nicméně vyloučit, že by se mohlo jednat o samostatně odlitou terčovitou hlavici jehlice, které jsou mladší, bez dorsálního obvodového žebírka a většinou s výraznějším středovým hrotem a odlišnou kompozicí výzdoby (srov. Gedl 1983, 59-65; Říhouský 1979, 39-42). Do jisté míry analogické výzdobné kompozice lze nalézt 
na kotoučovitých týlech sekeromlatů (např. David 2002, Taf. 4: 3, 4, 16; 50: 1a), tím však srovnání končí, protože inkriminovaný terčík těmto sekeromlatům neodpovídá ani tvarem, ani hmotově, navíc na jeho ventrální straně chybí jakákoliv stopa po odlomení nebo sekundární úpravě. Morfotypologicky tak terčík nejlépe odpovídá litým terčovitým závěskům, s nimiž jej může spojovat i nepravidelný otvor zhotovený při lití, který při absenci jindy přítomného poutka nebo pravidelného otvoru kruhového sloužil k uchycení (srov. např. Bóna 1975, Taf. 266: 1, 2; 267: 6, 9, 11; 269: 8, 13; 270: 10, 20, 21; Furmánek 1980, 12, Taf. 4: 80-82, 86, 88; Hänsel 1968, Taf. 1: 6, 9; 2: 19, 21; Mozsolics 1967, Taf. 24: 3, 4; 31: 10, 14). Lícní výzdobu těchto terčovitých závěšků tvoří nejčastěji žebírka ve tvaru křiže (odtud také termín „Kreuzrippenanhänger“: Bóna 1975, 219; Furmánek 1980, 12; Hänsel 1968, 118-119; Mozsolics 1967, 91), která jsou někdy doplněná výčnělky či obvodovými žebírky. Bohatá vhloubená výzdoba terčíku v depotu Moravský Krumlov 3 je však neobvyklá, celkovou kompozicí dokonce unikátní. Zatím snad jedinou, i když jednodušší obdobou by mohla být výzdoba na terčíku z hrobové výbavy v chorvatském Bjelo Brdo (Hänsel 1968, 243, Taf. 14: 30). Podstatné je, že bez ohledu na rozdíly ve výzdobě jsou tyto lité terčíky jak chronologicky, tak chorologicky signifikantní. Nálezovými celky jsou spolehlivě datovány do staršího stupně střední doby bronzové s hlavní oblastí výskytu v Karpatské kotlině a jejím okolí (Furmánek 1980, 12; Hänsel 1968, 118-119; Mozsolics 1967, 91-92).

\subsection{Ostatní artefakty}

Do kategorie šperků můžeme ještě zařadit spirálovitou trubičku (obr. 6: 9), patrně také částečně deformovaný plechový zlomek s výzdobou drobných pukliček (obr. 6: 10) a zlomek tyčinky kvadratického profilu (obr. 6: 11). Spolehlivě je typologicky klasifikovatelná pouze spirálovitá trubička, i když jinak je kulturně-chronologicky zcela irelevantní, se širokým časoprostorovým rozptylem výskytu. Zbývající dva fragmenty nelze typologicky blíže klasifikovat, deformovaný zlomek tyčinky (obr. 6: 11) by snad mohl pocházet z kruhového šperku.

Typologicky i funkčně zůstává sporná také geometricky pravidelná tyčinka kruhového profilu s jedním koncem přirozeně rovným a druhým stejnoměrně ostře zahroceným (obr. 6: 15). Vzhledem ke štíhlému a rovnoměrnému profilu i geometricky dokonalému tvaru ostře vymezeného hrotu lze vyloučit, že by to mohl být hrot jehlice, současně ale nelze vyloučit, že hrot je výsledkem reutilizace jiného artefaktu. Ve stávající podobě jej lze považovat snad za rydlo či stilus.

Další dva drobné ploché, v profilu jen mírně oblé zlomky (obr. 6: 13, 14) mají celý obvod tvořený lomy a jsou zcela neklasifikovatelné. Lze jen předpokládat, že pocházejí z finálních odlitků.

\subsection{Výrobní složky}

Výrobní složky jsou v obsahu depotu zastoupeny až třemi technologicky různými fázemi. Plochá, v profilu lehce bikonvexní tyčinka představuje kvalitní dokonalý odlitek, jehož obě podélné strany a jeden prŕícný konec tvoří ostré pravidelné hrany, druhý příčný konec je mírně oblý a kolmý, ploška je zde vzhledem k ostatnímu hladkému povrchu mírně drsná, ale přirozená (obr. 6: 12). Za daného stavu je obtížné tuto tyčinku typologicky i funkčně determinovat. Lze uvažovat snad o polotovaru (náramku?) nebo obecněji tyčinkovitém ingotu. Tyčinkovité ingoty různých tvarů, resp. profilů a velikostí se vyskytují v moravských i jiných depotech průběžně po celou střední a mladší do- 
bou bronzovou (Salaš 2005, 129; Mozsolics 1985, 32-33). V rámci střední doby bronzové byly dosud doloženy v depotech Hodonín a Hulín, kde jsou tyto ingoty ale nepravidelně hranolovité až trapezovité, strukturou kompaktní i porézní se staženinami (Salaš 2005, 129, tab. 2: 19; 3: 20; 27: 152). Zlomek jiného typu masivnějšího, v profilu lehce oválného ingotu s postranními odlévacími švy pochází ze středočeských Senomat, jeho příslušnost $\mathrm{k}$ tamnímu staromohylovému depotu je však sporná (Smejtek 2015; Stolz et al. 2015, 555, 569, obr. 13: A51, tab. 1). Citované příklady se však od krumlovského exempláře odlišují hrubším provedením jak povrchu, tak hmoty, a ne tak dokonalým, až geometricky pravidelným tvarem. Obdobně to nakonec platí i pro porovnání s tyčinkovitými ingoty v depotech doby popelnicových polí, alespoň na Moravě (srov. Salaš 2005, 129), v jiných regionech to však s ohledem na většinou nedostačující deskripci a vyobrazení v literatuře nelze objektivně posoudit (srov. Mozsolics 1985, 32). I když kvalitou provedení se na Moravě v době popelnicových polí přibližně srovnatelné kusy najdou (např. Polešovice: Salaš 1997, Taf. 26: 826; 27A: 827; Drslavice 2: Salaš 2005, tab. 171: 384), co do dokonalosti a zejména tvaru se přesnější analogii zatím nepodařilo dohledat. Dokonalost povrchu i celkového provedení odlitku tak jeho interpretaci jakožto ingotu či polotovaru př́iliš nenasvědčuje.

Zlomky kovových, s největší pravděpodobností měděných (analýzy složení zatím nebyly provedeny) slitků tvoří množstvím 28 ks nejpočetnější složku obsahu depotu (63,6 \%). Rovnoměrně jsou zastoupeny okrajové zlomky i středové zlomky těl, technologicky jsou slitky značně variabilní, lomové plochy vykazují většinou staženiny, dorsální plochy jsou však zpravidla poměrně hladké a kompaktní. Slitky nejsou v depotech střední doby bronzové ničím výjimečným, a to ani v těch ze samého počátku střední doby bronzové. Př́kladem toho mohou být moravské depoty Hodonín, Hulín, Mušov 1, Přítluky 1 (Salaš 2005, 133), český depot Senomaty (Smejtek 2015) nebo bavorské depoty Ackenbach a Bühl (Rittershofer 1983, 302-305). Jihočeský depot Nová Ves 2 se zlomky slitků a křtěnovským sekeromlatem je kladen již na přelom starší a střední doby bronzové (Chvojka et al. 2009). Podobně tomu bude u dalšího depotu se slitky z jihočeského Temešváru (Smejtek 2015, 586) a v Bavorsku je jejich první výskyt doložen již ve stupni B A2 (Möslein 2008, 120121; Salaš 2005, 133 s další lit.).

$\mathrm{V}$ rámci staršího mohylového stupně (depotového horizontu Hodonín-Přítluky) se podobně jako v Moravském Krumlově 3 vyšší podíl slitků projevil v depotech Hodonín (73,7 \%) a Mušov $1(74,1 \%)$. V těch dvou depotech se objevují také objemnější a těžší slitky, např. v Hodoníně je sedm zlomků o hmotnosti větší jak 1000 g, v Mušově 1 je průměrná hmotnost zlomku slitku 303 g (Salaš 2005, 262-264, 279). Naproti tomu v Moravském Krumlově 3 nejtěžší slitek váží 100 g, všech 28 kusů váží celkem 632 g a průměrná hmotnost slitku je tak pouze 22,6 g.

Celý atypický plochý a hrubší odlitek pravoúhlého tvaru (obr. 6: 16) téměř jistě do kategorie slitků nepatří. Jeho interpretace sice není zcela jednoznačná a spolehlivá, ale nejspíše by se mohlo jednat o druh výrobního odpadu, snad bronzovinu, která zatekla mimo odlévací formu nebo mezi jednotlivé díly složeného kadlubu.

\section{Chronologicko-kulturní postavení depotu}

Depot Moravský Krumlov 3 lze na základě především sekerek, spirálovitého náramku, jehlice a terčovitého závěsku v daném prostředí spolehlivě datovat do staršího stupně SMK, který je synchronizován se stupněm B B1 (např. Furmánek 1973, 128-129; Benkovsky-Pivovarová 1985, 


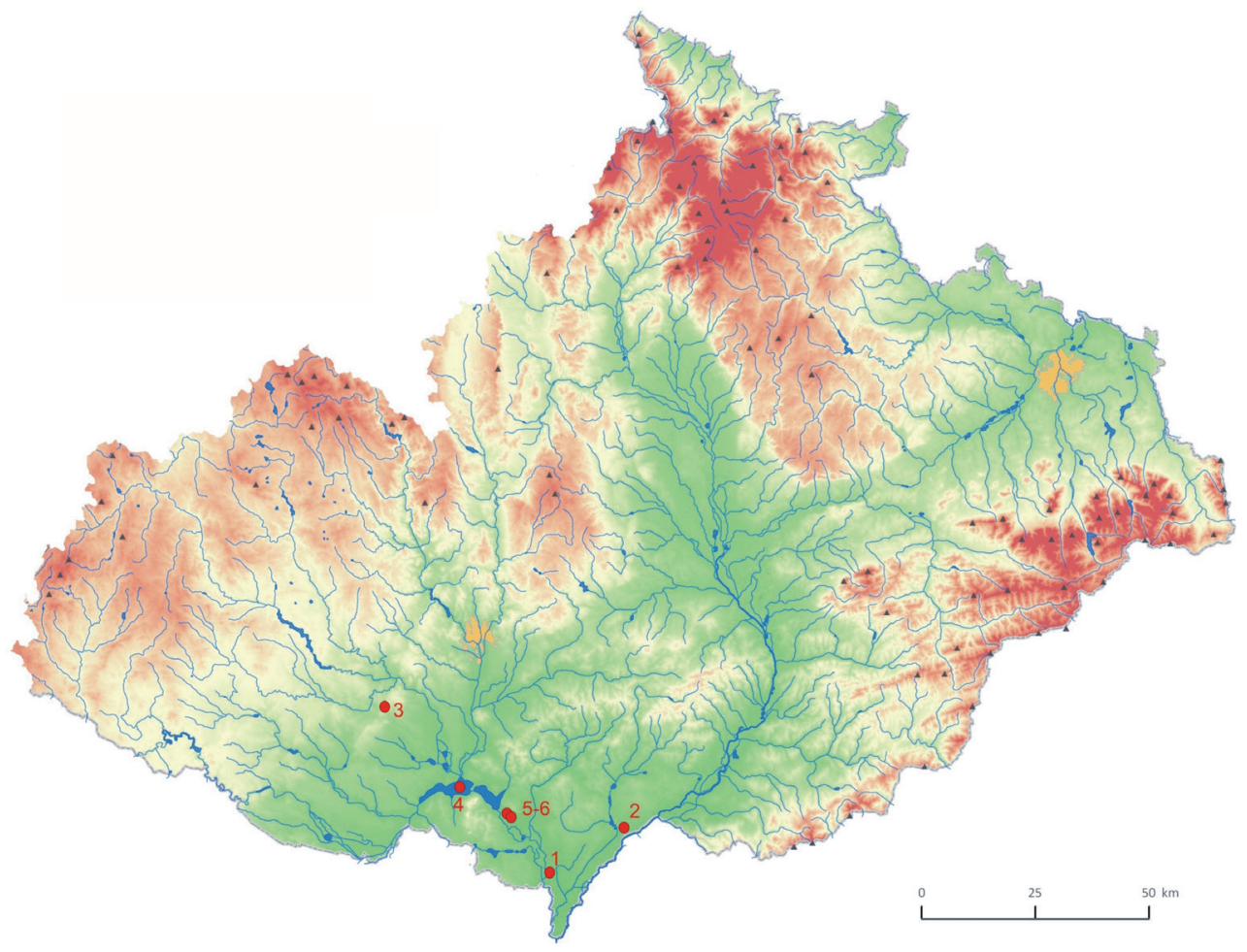

Obr. 9. Kovové depoty horizontu Hodonín-Přítluky (stupně B B1) na Moravě. 1 - Břeclav, 2 - Hodonín, 3 - Moravský Krumlov 3, 4 - Mušov 1, 5 - Př́tluky 1, 6-Př́tluky 2.

Fig. 9. Metal hoards of the horizon Hodonín-Př́tluky (stage B B1) in Moravia. 1 - Břeclav, 2 - Hodonín, 3 - Moravský Krumlov 3, 4 - Mušov 1, 5 - Prítluky 1, 6 - Prítluky 2.

85-91; Neugebauer 1994, 145-152; Stuchlik 2006, 224-225). Na Moravě tedy náleží depotovému horizontu Hodonín-Př́itluky, do kterého zatím spadalo pět depotů - Břeclav, Hodonín, Mušov 1, Přítluky 1 a Př́tluky 2 (Salaš 2005, 133-135). Pro jejich skladbu je obtížné najít společné jmenovatele. Vyskytují se převážně s typologicky i funkčně heterogenním složením, pouze Přítluky 2 jsou tvořeny výhradně náramky. Jinak jsou v nich zastoupeny všechny funkční kategorie artefaktů - nástroje, zbraně i šperky, v některých nechybí ani slitky (Hodonín, Moravský Krumlov 3, Mušov 1, Přítluky 1), v Hodoníně a Hulíně jsou zastoupeny i tyčinkovité ingoty (snad také v Moravském Krumlově 3) a Hodonín obsahuje také unikátní tyglíky (Salaš
2005, 62). Zbraně chybí v depotech Hodonín, Mušov 1, Přítluky 2 a také v Moravském Krumlově 3. Zastoupením typologických tříd (taxonů) je Moravskému Krumlovu 3 nejbližší depot Hodonín, nebot v obou celcích jsou zastoupeny sekerky, srpy, náramky, jehlice a slitky.

Pomineme-li typologicky klasifikovatelné artefakty se širším geografickým výskytem a chorologicky tak bez vypovídací hodnoty (č. 2, 4, 7, 9), jsou z provenienčního hlediska v depotu zastoupeny artefakty jak vysloveně autochtonní (č. 1), tak vnitrokarpatské, resp. severokarpatské $(\check{c} .6,8)$ provenience. To dobře koreluje se skladbou většiny ostatních moravských depotů horizontu Hodonín-Přítluky, ve kterých se promítají karpatské vlivy nebo př́imo impor- 
ty, a proto také byly tyto staromohylové depoty přirovnány $\mathrm{k}$ jihozápadoslovenské skupině kosziderských depotů a označeny dokonce za nejseverozápadněji vysunutou skupinu karpatských depotů kosziderského horizontu (Salaš 2005, 133).

$\mathrm{Z}$ prostorového hlediska bylo pro depoty horizontu Hodonín-Přítluky příznačné, že všech pět dosud známých zástupců se soustředilo kolem dolních toků Moravy a Dyje, popř. blízko soutoku Svratky s Dyjí a Dyje s Moravou (obr. 9). Depot Moravský Krumlov 3 je tak v rámci této depotové skupiny vysunutý nejseverněji a současně bude ve středním Podunají jedním z nejsevernějších depotů stupně B B1, který již obsahuje kovové (měděné?) slitky.

\section{Sídelně topografický kontext a depozitní areál Krumlovského lesa}

Geomorfologický okrsek Krumlovského lesa s charakterem vrchoviny nebyl v době bronzové agrární sídelní oblastí, byl jí však obklopen a tvořil funkční komponentu sídelní struktury, specifický areál oikumeny, a to včetně hradiska na Réně (Salaš 2018). S ohledem na datování depotu Moravský Krumlov 3 to lze dobře demonstrovat i ve střední době bronzové, a to jak v samotném areálu Krumlovského lesa, tak v jeho nejbližším, již agrárním okolí.

Osídlení středodunajskou mohylovou kulturou kolem jižní části Krumlovského lesa je co do množství lokalit bez ohledu na jejich bližší datování srovnatelné se starší dobou bronzovou či s dobou popelnicových polí. Ve vzdálenosti do zhruba $5 \mathrm{~km}$ od sledovaného depotu se západním až jihozápadním směrem na katastrech Moravského Krumlova, Lesonic a Rybníků nachází nejméně šest sídlišt, u Rybníků pak dokonce tři pohřebiště, $\mathrm{z}$ toho nejbližší je sídliště v poloze Vinohrady u Rakšic (Salaš 2009, 24-25 s další lit.), vzdálené od depotu cca 2,2 km. Východně až jihovýchodně od Krumlovského lesa se nejbližší mohylové sídliště, od depotu vzdálené 2,1 km, nachází ve Vedrovicích u kostela (Podborský - Vildomec 1972, 226; Stuchlik 1979, 67). Další sídliště SMK na východním okraji Kubšic (Podborský - Vildomec 1972, 181; Schirmeisen 1929, 8-10) je již vzdálené kolem $5 \mathrm{~km}$ a jako jedno z mála je lze přesněji datovat, a to do mladšího mohylového stupně. Jinak citované lokality nebyly podrobněji zpracovány a vyhodnoceny a většinou je nelze blíže datovat, jistě však nebyly všechny současné. Dva Krumlovskému lesu nejbližší kovové depoty Kubšice a Vedrovice 1 jsou rovněž nesporně mladší, Kubšice datované až do horizontu Hradisko-Hulín a poněkud sporný depot Vedrovice 1 rámcově nejspíše do středního až pozdního mohylového stupně ( $S a$ laš 2005, 135-139, 276-279, 284-285).

V samotné jižní části Krumlovského lesa není depot Moravský Krumlov 3 jediným kovovým depozitem střední doby bronzové. Kromě dalšího, zatím nepublikovaného depotu dvou masivních litých C náramků (Moravský Krumlov 4) zde byly pomocí detektoru objeveny i dva solitérní bronzové artefakty (srp s trnem, litý C náramek), které lze vzhledem k jejich velikosti a kompletnosti klasifikovat jako monodepozita. Připojíme-li k tomu obdobně objevený únětický depot kruhových hřiven s očky (Moravský Krumlov 2: obr. 2), pak na poměrně malém prostoru necelých $2 \mathrm{~km}^{2} \mathrm{~s}$ maximální vzájemnou vzdáleností cca $1300 \mathrm{~m}$ se v rámci starší a střední doby bronzové kumulují přinejmenším tři poly- a dvě monodepozita (obr. 2; 10). Díky této mikroregionální koncentraci, která navíc asi nebude konečná, se tak přinejmenším jižní část Krumlovského lesa stává dalším příkladem multidepozitní lokality s makrokumulací depotů a jedním z depozitních areálů doby bronzové na Moravě.

$\mathrm{Z}$ prostorového a sídelně-topografického hlediska lze rozlišit dva druhy depozitních areálů, 


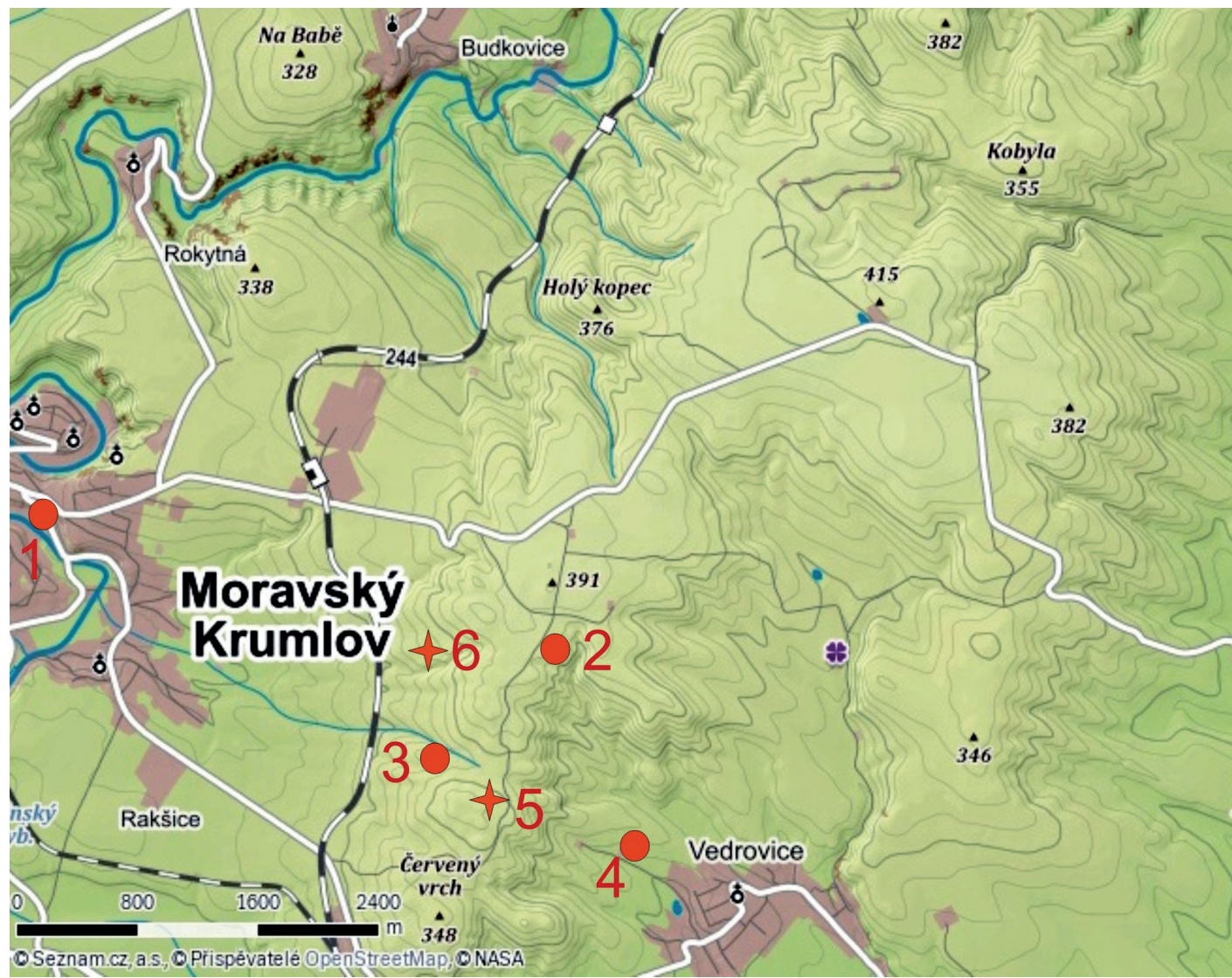

Obr. 10. Kovová depozita starší a střední doby bronzové v jižní části Krumlovského lesa a jeho nejbližším okolí (srov. obr. 2). Kolečko - depot, hvězdice - solitérní bronz. 1 - únětický depot Moravský Krumlov 1; 2 - únětický depot Moravský Krumlov 2; 3 - mohylový depot Moravský Krumlov 3; 4 - mohylový depot Moravský Krumlov 4; 5 - solitérní srp s trnem; 6 - solitérní náramek. Depot Vedrovice 1 blíže nelokalizován.

Fig. 10. Early and Middle Bronze Age metal hoards in the southern part of Krumlovský les and in its close neighbourhood (cf. Fig. 2). Dot - hoard, star - solitary bronze find. 1 - Únětice-Culture hoard Moravský Krumlov 1; 2 - Únětice-Culture hoard Moravský Krumlov 2; 3 - Tumulus-Culture hoard Moravský Krumlov 3; 4 - TumulusCulture hoard Moravský Krumlov 4; 5 - solitary tanged sickle; 6 - solitary bracelet. The findspot of the hoard Vedrovice 1 is not localised.

i když ne vždy přesně separovatelných a někdy se i prolínajících. Často vytvářejí depozitní areály mikrokumulace na výšinných, př́ípadně opevněných polohách se soudobým osídlením (srov. Salaš 2005, 195-198, obr. 77; 2018, 142-146, obr. 31-32). Pomyslným protějškem jsou pak prostorově volnější makrokumulace s metalickými poly- i monodepozity již mimo agrární, primární i sekundární oikumenu na okrajích navazujících vrchovin či pahorkatin. Zde pak náleží již do nárazníkové (terciérní) sféry sídelní struktury či v terminologii P. Pokorného (2011, 252) do oscilující periferie. Ideálním příkladem depozitních areálů v nárazníkové periferii mohou být na Moravě kumulace kolem Malé Hané (Salaš Jarišsková 2017) nebo depozita na severovýchodním okraji Drahanské vrchoviny na katastrech Žárovice - Hamry - Vícov (Salaš 2012, 201-203, Abb. 6; 2018, 142-143, obr. 31). Členitý reliéf jižního okraje hrástovité vrchoviny Krumlovské- 
ho lesa je nyní dalším příkladem tohoto druhu depozitního areálu. Zatímco ale všechny ostatní na Moravě dosud podchycené depozitní areály jsou datovány do doby popelnicových polí, většina depozit tohoto krumlovského je starší, z rozpětí klasické únětické kultury až závěru střední doby bronzové. Solitérní nálezy dvou srpů s řapem (jeden dosud nepublikovaný ze stejného areálu, druhý z polohy pod Holým kopcem na severovýchodním okraji Krumlovského lesa: Salaš 2006) jako dalších monodepozit prodlužují tento interval až do mladší doby bronzové. V tomto chronologickém ohledu je Krumlovský les na Moravě zatím unikátní, i když tato situace je velmi pravděpodobně dána stavem pramenů a jejich výzkumu, zvláště pokud jde o starobronzové depoty, kdy jejich starší publikace (Ondráček 1959; Tihelka 1965) již zdaleka nemohou vyhovovat a novější syntéza chybí. Pochopitelně zdaleka ne všechna kovová depozita doby bronzové jsou prvkem komponenty depozitních areálů, i zde však může situaci zkreslovat stav pramenné základny. Jak ukazují analogické kumulace depozit i v jiných oblastech (např. Bradley 2017; Fontijn 2012; Fröhlich - Chvojka - John 2015; Vachta 2012; 2017), nejsou depozitní areály žádným regionálním specifikem, naopak musí být obecnějším kulturním fenoménem.

Depot Moravský Krumlov 3 složením ani přesněji nezdokumentovanou nálezovou situací sám o sobě $\mathrm{k}$ depozitní interpretaci př́liš nepřispívá, ani samotná poloha nálezu není za současného terénního stavu nijak nápadná. ${ }^{2}$ Posuzováno komplexněji, v kontextu všech lokálních depozit a vzhledem $\mathrm{k}$ charakteru jejich krajinného prostředí, se již nabízejí interpretační alternativy srovnatelné s jinými depozitními areály v nárazníkové, oscilující periferii. V porovnání s jinými depozitními areály se však v případě Krumlovského lesa nabízí navíc další antropogenně velmi pozoruhodná a unikání sémantická konotace. Tou je nadčasová, chronologicky průběžná, i když ne zcela kontinuální těžba místních rohovců, která je na východních svazích Krumlovského lesa doložena mimo jiné ve starší době bronzové a později pak ještě i v době popelnicových polí (Oliva 2001; 2003; 2010, 307-308). Podstatnou okolností je, že tyto rozsáhlé a náročné exploatační davové aktivity postrádaly bezprostřední subsistenční účel, měly především transcendentální konotace a jejich význam se proto hledá v psychosociální a spirituální sféře (Oliva 2001, 350-356; 2002; 2003, 40-42; 2010, 320323; 2019). V Krumlovském lese se tak nacházejí dva areály starší až mladší doby bronzové - depozitní a exploatační. Prostorově se sice v detailech zatím přímo neprolínají, ale sousedí a chronologicky korelují ve starší a zřejmě i v mladší době bronzové, pro střední dobu bronzovou (stupně B B-B C, 15.-14. stol. BC) zatím těžba rohovců spolehlivě prokázána nebyla. Depozitní areály v oscilující periferii oikumeny lze ve většině pří padů spojovat se socio-kultovními rituály v kontextu sakrálně vnímané krajiny (srov. např. Fontijn 2002; Salaš - Jarůšková 2017, 127-131 s další lit.). Přihlédneme-li nyní také k výše reprodukované interpretaci důvodů a smyslu těžby rohovců, pak Krumlovský les jak optikou kovových depozit, tak surovinovou exploatací do koncepce sakrální percepce krajiny velmi dobře zapadá.

Recenzovaný odborný článek vznikl na základě institucionální podpory dlouhodobého koncepčního rozvoje výzkumné organizace poskytované Ministerstvem kultury (DKRVO, MK000094862).

1) V době zpracování příspěvku se depot nacházel ještě v držení nálezce, bude předán do Jihomoravského muzea ve Znojmě.

2) Mnohem výmluvnější je nálezová situace únětického depotu hřiven s očky Moravský Krumlov 2, který byl uložen uprostřed nápadné skupiny balvanů a který bude publikován na jiném místě. 


\section{Bibliografie}

Benkovsky-Pivovarová, Z. 1985: Das Bronzeinventar des mittelbronzezeitlichen Gräberfeldes von Pitten, Niederösterreich, Mitteilungen der Prähistorischen Kommission der Österreichischen Akademie der Wissenschaften 21-22, Wien 1982-1985, 23-105.

Benkovsky-Pivovarová, Z. - Chropovský, B. 2015a: Grabfunde der frühen und der beginnenden mittleren Bronzezeit in der Slowakei. Teil. 1. Nitra.

Benkovsky-Pivovarová, Z. - Chropovský, B. 2015b: Grabfunde der frühen und der beginnenden mittleren Bronzezeit in der Slowakei. Teil. 2. Nitra.

Benkovsky-Pivovarová, Z. - Stadler, P. 2019: Der bronzezeitliche „Übergangshorizont A2/B1“ aus der Sicht der Věteřov-Kultur, Pravěk NŘ 27, 43-74.

Bina, J. - Demek, J. 2012: Z nížin do hor. Geomorfologie České republiky. Praha.

Bóna, I. 1975: Die mittlere Bronzezeit Ungarns und ihre südöstlichen Beziehungen. Budapest.

Bradley, R. 2017: A Geography of Offerings: Deposits of Valuables in the Landscape of Ancient Europe. Oxford.

David, W. 2002: Studien zu Ornamentik und Datierung der bronzezeitlichen Depotfundgruppe Hajdúsámson-Apa-Ighiel-Zajta. Alba Iulia.

Fontijn, D. 2002: Sacrificial landscapes. Leiden.

Fontijn, D. 2012: Landscapes without boundaries? Some thoughts on Bronze Age deposition areas in north-west Europe. In: Hansen, S. - Neumann, D. - Vachta, T. (Hrsg.), Hort und Raum. Aktuelle Forschungen zu bronzezeitlichen Deponierungen in Mitteleuropa. Topoi Berliner Studies of the Ancient World 10. Berlin/Boston, 49-68.

Fröhlich, J. - Chvojka, O. - John, J. 2015: Čtyři mladobronzové depoty z vysokých poloh Píseckých hor, Archeologické výzkumy v jižních Čechách 28, 101-118.

Furmánek, V. 1973: Bronzová industrie středodunajské mohylové kultury na Moravě, Slovenská archeológia 20, 25-145.

Furmánek, V. 1980: Die Anhänger in der Slowakei. Prähistorische Bronzefunde XI, 3. München.

Gedl, M. 1983: Die Nadeln in Polen I. Prähistorische Bronzefunde XIII, 7. München.

Gedl, M. 1995: Die Sicheln in Polen. Prähistorische Bronzefunde XVIII, 4. Stuttgart.
Hampl, F. - Kerchler, H. - Benkovsky-Pivovarova, Z. 1981: Das mittelbronzezeitliche Gräberfeld von Pitten in Niederösterreich, Band 1, Mitteilungen der Prähistorischen Kommission der Österreichischen Akademie der Wissenschaften XIX-XX, Wien.

Hänsel, B. 1968: Beiträge zur Chronologie der mittleren Bronzezeit im Karpatenbecken. Bonn.

Chvojka, O. - Frána, J. - John, J. - Menšík, P. 2009: Dva depoty ze starší doby bronzové v areálu mohylového pohřebiště u Nové Vsi (okr. Český Krumlov), Archeologické rozhledy 61, 607-636.

Chvojka, O. - John, J. - Šálková, T. 2015: Nové kovové depoty ze starší doby bronzové v jižních Čechách. In: Bátora, J. - Tóth, P. (eds.), Ked' bronz vystriedal med'. Zborník príspevkov z XXIII. medzinárodného sympózia „Staršia doba bronzová v Čechách, na Morave a na Slovensku“. Levice 8.-11. Októbra 2013. Bratislava - Nitra, 421-432.

Kalábek, M. 2013: Charváty (okr. Olomouc), Přehled výzkumů 54-1, 179.

Mozsolics, A. 1967: Bronzefunde des Karpatenbeckens. Depotfundhorizonte von Hajdúsámson und Kosziderpadlás. Budapest.

Mozsolics, A. 1985: Ein Beitrag zum Metallhandwerk der ungarischen Bronzezeit, Bericht der Römisch-Germanischen Kommission 64, 1984, 19-72.

Möslein, S. 2008: Frühbronzezeitliche Depotfunde im Alpenvorland - neue Befunde. In: Schmotz, K. (Hrsg.), Vorträge des 26. Niederbayerischen Archäologentages, Rahden/Westf., 109-130.

Neugebauer, J.-W. 1994: Bronzezeit in Ostösterreich. St. Pölten-Wien.

Novotná, M. 1980: Die Nadeln in der Slowakei. Prähistorische Bronzefunde XIII, 6. München.

Oliva, M. 2001: Exploatační oblast rohovce v Krumlovském lese v době popelnicových polí a význam pozdních štípaných industrií, Pravěk NŘ 10, 2000, 335-364.

Oliva, M. 2002: Těžní jámy, rondely, hradiska... jak se to rýmuje? In: Neustupný, E. (ed.), Archeologie nenalézaného. Praha - Plzeň, 153-186.

Oliva, M. 2003: O nezanedbatelnosti neočekávatelného: štípané industrie starší doby bronzové na Moravě, Archeologické rozhledy 55, 14-46.

Oliva, M. 2010: Pravěké hornictví v Krumlovském lese. Vznik a vývoj industriálně-sakrální krajiny na jižní Moravě. Brno. 
Oliva, M. 2019: Těžba a rituál, pamět a transformace. Uzavírky šachet a obětiny $\mathrm{z}$ doby bronzové $\mathrm{v}$ Krumlovském lese. Brno.

Ondráček, J. 1959: Depot z Prušánek a únětické hřivny na Moravě, Pravěk východní Moravy I, 1958, 17-47.

Pászthory, K. - Mayer, E. F. 1998: Die Äxte und Beile in Bayern. Prähistorische Bronzefunde IX, 20. Stuttgart.

Podborský, V. - Vildomec, V. 1972: Pravěk Znojemska. Brno.

Pokorný, P. 2011: Neklidné časy. Kapitoly ze společných dějin přírody a lidí. Praha.

Primas, M. 1986: Die Sicheln in Mitteleuropa I (Österreich, Schweiz, Süddeutschland). Prähistorische Bronzefunde XVIII, 2. München.

Rittershofer, K.-F. 1983: Der Hortfund von Bühl und seine Beziehungen, Bericht der Römisch-Germanischen Kommission 64, 139-415.

Řihovský, J. 1979: Die Nadeln in Mähren und im Ostalpengebiet. Prähistorische Bronzefunde XIII, 5. München.

Říhovský, J. 1989: Die Sicheln in Mähren. Prähistorische Bronzefunde XVIII, 3. München.

Řihovský, J. 1992: Die Äxte, Beile, Meißel und Hämmer in Mähren. Prähistorische Bronzefunde IX, 17. Stuttgart.

Salaš, M. 1997: Der urnenfelderzeitliche Hortfund von Polešovice und die Frage der Stellung des Depotfundhorizonts Drslavice in Mähren. Brno.

Salaš, M. 2005: Bronzové depoty střední až pozdní doby bronzové na Moravě a ve Slezsku. Brno.

Salaš, M. 2006: Budkovice (okr. Brno-venkov), Přehled výzkumů 47, 137.

Salaš, M. 2009: Nejstarší obyvatelé přicházejí. Vývoj pravěkého osídlení Moravskokrumlovska. In: Fišer, Z. (ed.), Moravský Krumlov ve svých osudech. Brno, 11-30.

Salaš, M. 2012: Mikro- und makroräumliche Zusammenhänge der urnenfelderzeitlichen Hortfunde auf Höhenanlagen in Mähren. In: Hansen, S. - Neumann, D. - Vachta, T. (Hrsg.), Hort und Raum. Aktuelle Forschungen zu bronzezeitlichen Deponierungen in Mitteleuropa. Topoi Berliner Studies of the Ancient World 10. Berlin/Boston, 199-209.

Salaš, M. 2015: Kovová depozita únětické kultury z výšinné polohy u Rešic (okr. Znojmo). In: Bátora, J. - Tóth, P. (eds.), Ked' bronz vystriedal med'. Zborník príspevkov z XXIII. medzinárodného sympózia „Staršia doba bronzová v Čechách, na
Morave a na Slovensku“. Levice 8.-11. októbra 2013. Bratislava - Nitra, 391-414.

Salaš, M. 2018: Kovová depozita mladší doby bronzové z hradiska Réna u Ivančic. Brno.

Salaš, M. - Jarišsková, Z. 2017: Poznámky k současnému stavu fondu metalických depotů doby popelnicových polí v regionu Malé Hané, Pravěk NŘ 25, 121-138.

Salaš, M. - Śálková, T. - Houfková, P. - Kmošek, M. 2020: Metalický depot z doby popelnicových polí z Babího lomu u Svinošic (okr. Blansko) a výpověd' jeho kulturně-chronologického, sémantického a environmentálního kontextu, Archeologické rozhledy 72, 26-66.

Schirmeisen, K. 1929: Beiträge zur mährischen Vorgeschichte, Sudeta 5, 1-14.

Smejtek, L. 2015: Senomaty: př́spěvek k poznání bronzových depotů stupně Br B1 v Čechách, Archeologie ve středních Čechách 19, 573-591.

Stolz, D. - Smejtek, L. - Blažková, K. - Hradec, P. - Stolzová, D. - Šimal. Z. 2015: Středobronzový depot ze Senomat, okr. Rakovník, Archeologie ve středních Čechách 19, 551-571.

Stuchlik, S. 1979: K poznání vzniku a staršího vývoje lidu středodunajské mohylové kultury na jižní Moravě IIII. Nepubl. rkp. kandidátské disertace. Brno.

Stuchlik, S. 1981: Depot středodunajské mohylové kultury z Mušova, Archeologické rozhledy 33, 361-370, 477.

Stuchlik, S. 2006: Borotice. Mohylové pohřebiště $\mathrm{z}$ doby bronzové. Brno.

Tihelka, K. 1965: Hort- und Einzelfunde der Úněticer Kultur und des Věteřover Typus in Mähren. Brno 1965.

Vachta, T. 2012: Multidepotfundstellen in Böhmen. In: Hansen, S. - Neumann, D. - Vachta, T. (Hrsg,), Hort und Raum. Aktuelle Forschungen zu bronzezeitlichen Deponierungen in Mitteleuropa. Topoi Berliner Studies of the Ancient World 10. Berlin/Boston, 179-197.

Vachta, T. 2017: Bronzezeitliche Hortfunde und ihre Fundorte in Böhmen. Berlin.

Vích, D. 2020: Třetí depot doby bronzové z Jevíčka na Malé Hané. In: Mitáš, V. - Ožd’áni, O. (eds.), Doba popelnicových polí a doba halštatská. Zborník príspevkov z XV. Medzinárodnej konferencie Doba popelnicových polí a doba halštatská. Smolenice 15.-19. október 2018. Nitra, 233-239. 


\section{Der mittelbronzezeitliche Metallhortund Moravský Krumlov 3 und Kromauer Wald als ein weiteres Beispiel der multideponierenden Sakrallandschaft}

Die meisten Metallhorte, die in den letzten zwanzig Jahren mit Hilfe von Metalldetektoren in Mähren entdeckt wurden, sind in die Urnenfelderzeit datiert. Aus der Frühbronzezeit wurden nur zwei neue Depotfunde veröffentlicht (Kalábek 2013; Salaš 2015) und ein Depotfund fällt ans Ende der Mittel- oder den Anfang der Spätbronzezeit (Vich 2020). Einige neue früh- und mittelbronzezeitliche Metallhorte wurden im Katasterbezirk von Moravský Krumlov im Südteil des Kromauer Waldes entdeckt (Abb. 1). Im Anschluss an einen älteren Barrenhort der Aunjetitzer Kultur aus Moravský Krumlov - Rakšice (Ondráček 1959, 40; Salaš 2009, 20-21; Tihelka 1965, 23) wurde ein weiterer neuer Barrenhort als Moravský Krumlov 2 und zwei mittelbronzezeitliche Horte als Moravský Krumlov 3-4 bezeichnet (Abb. 2). Von ihnen wird im vorliegenden Beitrag der Hort Moravský Krumlov 3 vorgestellt und ausgewertet. Diesen Hort entdeckte man mit Hilfe eines Metalldetektors im Jahr 2013 auf einem mäßigen nordwestlichen Hang in einer Höhe von $333 \mathrm{~m}$ ü. d. M. (Abb. 3), wo das Terrain dann in nordöstlicher Richtung allmählich in eine Talenge mit einem namenlosen Wasserlauf abfällt (Abb. 4). Die Gegenstände waren dort in einem Haufen 15-20 $\mathrm{cm}$ tief unter einem Stein deponiert (Abb. 5).

In der Zusammensetzung des Depots sind außer Gußkuchen auch Werkzeuge und Schmuck vertreten (Abb. 6-8). Von den drei vertretenen Beilen lassen sich zwei Exemplare typologisch den Absatzbeilen zuordnen. Das erste von ihnen (Abb. 6: 1) gehört zur siebten Gruppe nach J. Říhovský (1992, 127-128), die in Mähren bisher nur durch fünf Einzelfunde vertreten war. Das Beil in diesem Hort stellt somit das erste Exemplar in einem Fundkomplex dar. Außerhalb des Gebietes von Mähren treten die Beile dieser Gruppe nur selten auf und lassen sich daher als ein autochthones Element betrachten. Aufgrund der Verwandtschaft mit Beilen mit herzförmigem oder abgerundetem Leistenabsatz werden diese Formen mit der älteren Stufe der mitteldonauländischen Hügelgräberkultur in Zusammenhang gebracht (Ľihovský
1992, 128). Das zweite Absatzbeil (Abb. 6: 2) gehört dem fünften Typ an, der unter den Horten bislang nur in Hodonín vertreten war. Damit ist es schon in die ältere Stufe der Hügelgräberkultur und in den Depotfundhorizont Hodonín-Přítluky datiert (Řihovský 1992, 124-125; Salaš 2005, 32-33, 132-133).

Zwei Fragmente von Sicheln (Abb. 6: 4-5) lassen sich nicht zuverlässig typologisch klassifizieren. Die Position des Knopfes in der Mitte der Nackenpartie unter der Ebene der inneren Rippe, genauso wie die Verlängerung dieser Rippe bis zum Nacken hin (Abb. 6: 4) sind etwas ungewöhnlich. Annähernde Analogien finden wir in den Horten Př́itluky 1 und Hodonín (Řihovský 1989, Taf. 1: 1, 4, 5; 5: 62), beziehungsweise Uzd oder Ackenbach (Mozsolics 1967, Taf. 54: 4, 8, 10; Primas 1986, Taf. 4: 67; Rittershofer 1983). Diese Fundkomplexe sind ebenfalls in die Anfangsstufe der Mittelbronzezeit, d. h. in die Stufe B B1 nach Reinecke datiert. Die Armspirale mit Spiralscheibenenden (Abb. 6: 6) findet anhand der Form der Ränder und Verzierung eine Analogie in den Blechspiralen aus dem Hort Mušov 1 (Stuchlik 1981, 361-363, obr. 2: 5, 7, 10) oder aus dem Grab 22 des Gräberfeldes von Pitten (Hampl - Kerchler - Benkovsky-Pivovarová 1981, 30, Taf. 203:1; Benkovsky-Pivovarová 1985, 61). Chronologisch und räumlich handelt es sich um einen empfindlichen Gegenstand, denn Spiralen in dieser Ausführung stellen vor allem innenkarpatischen Schmuck dar, der für den Koszider-Horizont und damit im Prinzip für die Stufe B B1 kennzeichnend ist (Salaš 2005, 100-101 mit weiterer Lit.). Deren Funde westlich des Karpatenbogens, einschließlich jener aus Mähren, lassen sich damit als ein Ergebnis der karpatischen Einflüsse betrachten.

Das Fragment eines Nadelschafts gehört anhand des rosettenförmigen Querschnitts (Abb. 6: 7) einer Lochhalsnadel an. Bei der Absenz des Halses und Kopfes lässt sich der konkrete Typ aber nicht genau identifizieren (Řihouský 1979, 20-33). Die Nadeln mit derartig profiliertem Schaft sind in den Horten aus Mähren bisher nicht vorgekommen. Außerhalb 
von Mähren erscheinen solche Exemplare jedoch üblicherweise in Gräbern, die einheitlich in die ältere Stufe der Hügelgräberkultur, d. h. in die Stufe B B1 nach Reinecke datiert sind (Benkovsky-Pivovarová, 1985, 29-34; Benkovsky-Pivovarová - Chropovský 2015b, 56-57, alles mit älterer Lit.).

Die gegossene Scheibe (Abb. 6: 8; 7) kann man typologisch als scheibenförmigen Anhänger klassifizieren. Seine Verzierungskomposition auf der Stirnseite ist einzigartig, als die nächste Analogie dazu bietet sich die Verzierung auf einer Scheibe aus der Grabausstattung in Bijelo Brdo (Hänsel 1968, 243, Taf. 14: 30). Diese Scheiben sind durch die Fundkomplexe zuverlässig in die ältere Stufe der Mittelbronzezeit datiert, mit dem Hauptvorkommen im Karpatenbecken und in seiner Umgebung (Furmánek 1980, 12; Hänsel 1968, 118-119; Mozsolics 1967, 91-92). Der Kategorie von Schmucksachen kann man noch ein Spiralröllchen (Abb. 6: 9) und zwei weitere typologisch nicht näher klassifizierbare Fragmente (Abb. 6: 10-11) zuordnen. Die übrigen Artefakte lassen sich entweder nicht typologisch identifizieren (Abb. 6: 12-15) oder sie stellen Fragmente von Gußkuchen (Abb. 6: 17-20; 8), bzw. Produktionsabfall (Abb. 6: 16) dar.

Den Hort Moravský Krumlov 3 kann man anhand der Beile, der Armspirale, Nadel und des Scheibenanhängers in die ältere Stufe der mitteldonauländischen Hügelgräberkultur datieren, die mit der Stufe B B1 synchronisiert ist. In Mähren fällt er somit in den Depotfundhorizont Hodonín-Přítluky, der bisher durch fünf Horte repräsentiert wurde (Salaš 2005, 133-135). Mit der Vertretung der typologischen Klassen steht dem Hort Moravský Krumlov 3 am nächsten der Hort Hodonín. Die beiden Fundkomplexe enthalten Beile, Sicheln, Armspiralen, Nadeln und Gußkuchen, die im Rahmen dieses Fundhorizontes in Mähren überhaupt zum ersten Mal auftreten. Die Hortfunde im Rahmen dieses Horizontes konzentrierten sich bisher entlang der Unterläufe der Flüsse March und Thaya, Moravský Krumlov 3 ist am meisten nach Norden vorgeschoben (Abb. 9). Hinsichtlich der Provenienz sind in diesen Horten neben autochthonen Gegenständen auch Einflüsse aus dem Karpatengebiet zu beobachten. Deswegen werden diese althügelgräberzeitlichen Depotfunde aus Mähren mit der südwestslowakischen Gruppe der Koszi-
der-Horte verglichen (Salaš 2005, 133).

Das Areal des Kromauer Waldes stellte in der Bronzezeit kein agrarisches Siedlungsgebiet dar, es war jedoch von einem solchen Gebiet umgeben, wovon die Siedlungen, Gräberfelder sowie Metallhorte in seiner Nahumgebung zeugen. Viele von ihnen datieren auch in die Mittelbronzezeit (Salaš 2009, 24-25 mit weiterer Lit.) und sind damit ungefähr zeitgleich mit dem Hort Moravský Krumlov 3. Im Südteil des Kromauer Waldes handelt es sich dabei nicht um den einzigen mittelbronzezeitlichen Metallhort - bei Sondenbegehungen entdeckte man noch ein weiteres Depot von zwei Armbändern (Moravský Krumlov 4) und zwei Einzelfunde - eine Sichel und ein Armband. Zusammen mit dem Barrenhort der Aunjetitzer Kultur (Moravský Krumlov 2) konzentrieren sich also innerhalb eines relativ kleinen Raums wenigstens drei Poly- und zwei Monodepots (Abb. 2; 10). Der Südteil des Kromauer Waldes wird damit zu einem weiteren Beispiel einer Multidepot-Fundstelle mit einer Makrokumulation von Horten und zu einem der bronzezeitlichen Deponierungsareale in Mähren. Diese Makrokumulationen von Horten befinden sich gewöhnlich schon außerhalb der agrarischen, primären sowie sekundären Ökumene, an der Peripherie des anschließenden Berg- oder Hügellandes und gehören somit zu der (oszillierenden) Pufferzone der Siedlungsstruktur (vgl. z. B. die Deponierungsareale rund um Malá Haná: Salaš - Jarůšková 2017).

Sämtliche bisher in Mähren identifizierte Deponierungsareale sind in die Urnenfelderzeit datiert. Die meisten Depots aus diesem Kromauer Areal sind dagegen älter und stammen aus dem Intervall von der klassischen Aunjetitzer Kultur bis zum Ende der Mittelbronzezeit. Der Kromauer Wald ist in dieser Hinsicht in Mähren bislang einzigartig, obwohl diese Situation höchstwahrscheinlich durch den Stand der Quellenkenntnis gegeben ist. Analogien zu diesen Kumulationen von Horten aus anderen Regionen (z. B. Bradley 2017; Fontijn 2012; Fröhlich - Chvojka - John 2015; Vachta 2012; 2017) zeugen davon, dass die Deponierungsareale kein regionales Spezifikum, sondern ein allgemeineres Kulturphänomen darstellen. Im Vergleich zu anderen Deponierungsarealen bietet sich im Fall des Kromauer Waldes obendrein eine bemerkenswerte anthropogene und einzigartige 
semantische Konnotation - der überzeitliche, chronologisch durchlaufende, obwohl nicht völlig kontinuierliche Abbau von örtlichen Hornsteinen, der unter anderem in der Frühbronzezeit und später dann auch noch in der Urnenfelderzeit belegt ist. Er hatte vor allem transzendentale Konnotationen und nach seiner Bedeutung sucht man in der psychosozialen und spirituellen Sphäre (Oliva 2001; 2002; 2003; 2010, 307-308, 320-323). Im Kromauer Wald befinden sich also zwei bronzezeitliche Areale - das Deponierungs- und das Abbauareal, die zumindest in der Frühbronzezeit chronologisch korrelieren. Die
Deponierungsareale in der oszillierenden Peripherie der Ökumene lassen sich in den meisten Fällen mit sozial-kultischen Ritualen im Kontext einer sakral wahrgenommenen Landschaft verbinden (vgl. z. B. Fontijn 2002; Salaš - Jarǐšková 2017, 127-131 mit weiterer Lit.). Berücksichtigen wir nun auch die obenerwähnte Interpretation der Begründung und Bedeutung des Hornsteinabbaus, dann passt der Kromauer Wald sowohl aus der Sicht der Metallhorte als auch des Rohmaterialabbaus sehr gut in die Konzeption einer sakralen Wahrnehmung der Landschaft.

\section{PhDr. Milan Salaš, CSc., DSc.}

- Archeologický ústav, Moravské zemské muzeum

Zelný trh 6, 65937 Brno, Česká republika

msalas@mzm.cz 